\title{
Identifying Levers Related to Student Performance on High-Stakes Science Exams: Examining School, Teaching, Teacher, and Professional Development Characteristics
}

\author{
Christian Fischer, ${ }^{1}$ Brandon Foster, ${ }^{2}$ Ayana McCoy, ${ }^{3}$ Frances Lawrenz, ${ }^{4}$ Chris Dede, ${ }^{5}$ \\ Arthur Eisenkraft, ${ }^{3}$ Barry J. Fishman, ${ }^{6}$ Kim Frumin, ${ }^{5}$ Abigail Jurist Levy ${ }^{2}$ \\ ${ }^{1}$ University of Tübingen, Germany \\ ${ }^{2}$ Education Development Center, Inc., USA \\ ${ }^{3}$ University of Massachusetts at Boston, USA \\ ${ }^{4}$ University of Minnesota, USA \\ ${ }^{5}$ Harvard University, USA \\ ${ }^{6}$ University of Michigan, Ann Arbor, USA
}

Pre-print for:

Fischer, C., Foster, B., McCoy, A., Lawrenz, F., Dede, C., Eisenkraft, A., Fishman, B., Frumin, K., \& Levy, A. (2020). Identifying levers related to student performance on high-stakes science exams: Examining school, teaching, teacher, and professional development characteristics. Teachers College Record, 122(2). https://www.tcrecord.org/Content.asp?ContentID=23024

Please note that this pre-print represents the manuscript version submitted for review and prior to changes from the peer review and copy-editing processes. The final peer-reviewed version appeared in the Teachers College Record. The article has been published and here is the link. 


\section{Identifying Levers Related to Student Performance on High-Stakes Science Exams: Examining School, Teaching, Teacher, and Professional Development Characteristics}

\section{Structured Abstract}

Background: Many students enter into postsecondary education without the college readiness skills that allow them to face the demands of postsecondary education. Increasingly, policymakers and educational researchers are responding to calls for reforming secondary education to provide more opportunity for all students to receive high quality education and to become career and college ready.

Purpose: This study attempts to identify levers to increase student performance in secondary education. In particular, it examines relationships of school, teaching, teacher, and teacher professional development characteristics with student scores on high-stakes Advanced Placement (AP) examinations in the sciences.

Setting: This study is situated in the context of the large-scale, top-down, nationwide AP curriculum and examination reform in the sciences (Biology, Chemistry, Physics) in the United States. This is an unprecedented opportunity to analyze changing educational landscapes in the United States with large-scale national student-, teacher-, school-, and district-level data sets across multiple science disciplines and different stages of the curriculum reform implementation connected to a standardized and high-stakes student outcome measure.

Population: This study analyzes nationwide data samples of the AP Biology, AP Chemistry, and AP Physics population during the first, second, and third year of the curriculum reform implementation. Across disciplines and years, the analytical samples include a total of 113,603 students and 6,046 teachers. 
Research design: This empirical quantitative study uses data from web-based surveys sent to all AP science teachers. Additionally, College Board provided student- and school-level data for all students taking AP examinations. Data preparation methods included exploratory and confirmatory factor analysis. Associations towards student achievement were analyzed through multi-level ordered logistic regression analysis separately by science discipline and year of the curriculum reform implementation. Afterwards, the results were aggregated through a metaanalysis.

Findings: Student performance is not pre-determined by students' background, leaving roughly $60 \%$ of the AP score variance potentially malleable for teacher and school-level factors. In particular, teachers' perceived administrative support, self-efficacy, teaching experience, and elements of classroom instruction were related to student performance. Notably, teachers' professional development participation has a small, mixed impact on student achievement. Conclusion: The identified levers for improving student achievement provide a strong rationale for the continued efforts of policy makers to improve school environments and to support science teachers to ultimately both increase student learning and help all students graduate prepared for college and ready for their future careers. 


\section{Identifying Levers Related to Student Performance on High-Stakes Science Exams: Examining School, Teaching, Teacher, and Professional Development Characteristics}

There is continued concern about whether students in the United States are ready to meet the demands of postsecondary education. Recent statistics show that roughly $28 \%$ of college freshman students who matriculate into 4-year institutions, and roughly $30 \%$ of college students who enter into 2-year institutions do not return for further studies (Kena et al., 2016). Meanwhile, for students who began college in 2009 , only $59 \%$ of students who set out to complete a Bachelor's degree finish within 6-years, and only $61 \%$ of students who set out to complete a 2-year degree finish (Kena et al., 2016). For students in STEM fields between 2003 and 2009, 48\% of bachelor's degree students and 69\% of associate's degree students left the STEM field by 2009 (Chen, 2013). These statistics indicate a large number of students enter into postsecondary education without the college readiness skills that allow them to face the demands of postsecondary education. Consequently, policy efforts have been targeted to improve student science achievement and postsecondary persistence rates of students in the United States (i.e., Framework for K-12 Science Education (National Research Council, 2012a), Next Generation Science Standards (NGSS; NGSS Lead States, 2013). Further, policymakers, as well as the business community, believe that the foundation of a successful $21^{\text {st }}$ century American labor market will depend on the effectiveness of these actions (National Academy of Sciences et al., 2007).

Policy-focused efforts to improve the college readiness of American students rely on having valid indicators for college readiness. Many policymakers believe that student performance on Advanced Placement (AP) tests, and in particular the AP science examinations, 
are key indicators of college readiness (Cromwell et al., 2013). In recent years, the College Board, the provider of the AP program, revised the AP examinations in the sciences (Biology, Chemistry, Physics) to respond to recommendations from the National Research Council (2002) to reduce its former emphases on rote learning and algorithmic procedures, and to increase emphases on scientific inquiry, reasoning, and depth of understanding. These changes are in-line with other recommended large-scale national curriculum shifts in the sciences such as the Framework for K-12 Science Education (National Research Council, 2012a) and the NGSS (NGSS Lead States, 2013). The AP Biology examinations were redesigned in 2013, followed by AP Chemistry in 2014 and AP Physics in 2015.

The AP program provides rigorous, college-level material to high school students across a broad range of subjects. The College Board defines the curriculum standards for AP courses, has them reviewed by faculty at over 100 different universities by professors teaching parallel courses, and offers corresponding examinations (i.e., the AP exams) to assess students' content mastery and scores AP exams on a 1-5 scale. Depending on the institution of higher education, students who earn a 3 or higher may use their scores towards college-level credit and/or for placement in higher level college courses. A unique aspect of AP course offerings is that there are no "official" College Board curriculum materials for courses. Before receiving the designation of an "Advanced Placement" course, teachers must develop their own curriculum plan, which must also be certified by the College Board or choose one presented by the College Board. Across teachers, this results in a variety of activities students could experience in their preparation for an AP exam. Despite the status of the College Board's AP exams as a leading indicator of college readiness, relatively little is known with regard to associations between school context factors and the revised AP science examinations. In order to increase the college 
readiness of students, it is important to identify factors that may predict students' success on high-stakes examinations which can be shaped or that are susceptible to intervention or policy reform initiatives. Knowledge of these associations might help to understand how these associations could be leveraged to affect policy initiatives aimed at improving student learning and achievement.

In particular, education policy research that focuses on positively affecting student outcomes typically makes the distinction between two types of variables from a student's context; namely, those factors of a student or his/her environment that are malleable by interventions, and those features that are considered intractable (i.e., socioeconomic status, race, gender) (e.g., Fives \& Buehl, 2016; Jackson, Rockoff, \& Staiger, 2014; Roegman \& Hatch, 2016; Teodorović, 2011). Most typically, researchers are interested in understanding the association between theoretically malleable factors and student outcomes, after controlling for student characteristics or contextual features from students' environments that are understood to be intractable, but to be associated with student outcomes (i.e., socioeconomic status, prior test scores). In terms of important features of a student's environment, much focus has been given to the role of teachers in promoting students' educational successes (Cohen \& Ball, 1999; Hattie, 2009, 2012; Seidel \& Shavelson, 2007). Even more recently, attention has been given to understanding how teachers respond to large-scale education reform agendas, such as the College Board's redesign of the AP examinations, with particular interests in understanding teacher and school characteristics that lead to successful implementation of reform initiatives (Fives \& Buehl, 2016). This is a natural progression for inquiry, as teachers are primarily responsible for enacting policy decisions, and their beliefs about teaching, beliefs about the abilities and strengths of their students, and subject specific knowledge all can combine to 
impact the fidelity and efficacy of the reform initiative and subsequent student outcomes (e.g., Buehl \& Fives, 2016; Fives \& Buehl, 2012). A specific goal of this paper is to investigate theoretically malleable teacher, teaching, and school characteristics that are correlated with students' performance on the redesigned AP science examinations, which could be used as levers for policy interventions.

\section{Literature Review}

\section{Importance of Student Characteristics for Student Performance}

Student characteristics account for large shares of variance in students' performance on standardized high-stakes examinations. Therefore, when modeling relationships with student achievement, it is imperative to account for such student characteristics to reduce omitted variable biases. In particular, students' prior performance on standardized tests such as the Preliminary Scholastic Aptitude Test (PSAT) are among the largest predictors of students' AP scores (Ewing et al., 2006, 2010; Zhang et al., 2014). Furthermore, researchers have used advanced econometric techniques to show that much of the predictive power of student aptitude tests is driven by student-level socioeconomic factors (Atkinson \& Geiser, 2009; Rothstein, 2004). In addition, students' family background is often considered an important factor in predicting student success. For instance, several research studies indicate associations of parental educational attainment with student achievement and success (Davis-Kean, 2005; Desforges \& Abouchaar, 2003; Fischer et al., 2018; Woessmann, 2004). However, despite the importance of student-level variables in predicting students' performance on tests like the AP science exams, these factors have typically been considered as fixed (i.e., not malleable), and as such less amenable to policy interventions. Therefore, researchers have increasingly focused on 
identifying potential levers on the school- and teacher level that might be associated with increases in student science achievement.

\section{Importance of School Characteristics for Student Performance}

At the school-level, researchers have identified several factors associated with student science achievement. It is theorized that school composition can be associated with several aspects of school and classroom context, which in turn can impact the quality of instruction students are exposed to, and subsequently their performance on high-stakes tests like the AP exam (Willms, 2010). In fact, the research has demonstrated that $15 \%$ of the student score variance on the PISA benchmark tests is explained by students' socioeconomic status (SES) (OECD, 2013). Because selection into schools is non-random, schools in high poverty areas tend to have the highest concentration of low SES students. The achievement gap in science and mathematics tends to be larger for these students when compared to their more affluent peers, and they also experience higher incidents of psychosocial problems (Crosnoe, 2009). Further, the socioeconomic stratification of students into schools is associated with high school graduation and college enrollment rates (Palardy, 2013). Further, school socioeconomic stratification has also been shown to effect associations with teacher expectations for their students' performance, how teachers enact instructional practices, as well as other indicators of teacher quality and student achievement (Brault et al., 2014; Nye et al., 2004; Sass et al., 2012; Supovitz \& Turner, 2000; Willms, 2010).

In order to buffer against these deleterious effects, many researchers have highlighted the importance of contextual factors such as administrative and principal support, which might be leveraged to provide necessary support to science teachers in order to improve their working conditions, and subsequently improve student achievement. For example, studies indicate that 
supportive work environments; coherent, mission-driven school cultures; and effective administrative leadership structures (i.e., structures that provide teachers with resources, opportunities to collaborate, and instill trust) are associated with increased teacher effectiveness and improved student performance (Johnson et al., 2012; Kraft et al., 2016; Ladd, 2009; Leithwood et al., 2004; Supovitz et al., 2010; van Geel et al., 2016; Waters et al., 2003). Taken in sum, the aforementioned research suggests that, while school socioeconomic status might appear to be an inevitable influencer of student achievement, some features of the school context can be leveraged to improve teacher working conditions, efficacy and student achievement.

\section{Importance of Teacher and Teaching Characteristics for Student Performance}

The role of teachers as the primary driver of student learning and performance has been widely accepted. As such, researchers have long focused on identifying systematic differences between teachers in their ability to raise student test scores, examining how important any potential systematic differences are for raising student test scores while accounting for fixed factors (i.e., family education, family income, etc.), and whether any potential differences in teacher quality are associated with observable characteristics of teachers and schools (Rivkin et al., 2005). The latter is popular among researchers within education reform circles, largely due to the belief that observable characteristics which are associated with teacher quality can be leveraged by policy initiatives to improve overall teacher quality and subsequent student learning (e.g., Cohen \& Ball, 1999; Hattie, 2009, 2012).

Among teacher characteristic variables, teachers' knowledge (i.e., subject matter knowledge, pedagogical content knowledge, curricular knowledge, Shulman, 1986) and teaching experience have been hypothesized as important predictors of both teacher quality and student outcomes (Hattie, 2012; National Research Council, 2005, 2012b). Teacher's instructional 
capacity grows with frequent and continuous interactions with students and materials (Cohen \& Ball, 1999). Thus, research consistently demonstrated that teachers' knowledge and experience is associated with increases in teachers' educational effectiveness and subsequent student achievement gains (e.g., Boyd et al., 2008; Daly, Moolenaar, Der-Martirosian, \& Liou, 2014; Keller, Neumann, \& Fischer, 2017; Nye et al., 2004; Wiswall, 2013). Similarly, teachers who can concentrate their years teaching on one grade-level are able to further increase their students' performance compared to teachers with similar overall teaching experience teaching a widerrange of grades (Ost, 2014). In addition, internal psychological constructs, such as personality, motivation, and normative beliefs, influence teachers' adoption of curriculum reforms and instructional enactments (Klassen \& Tze, 2014; Veal et al., 2016). For instance, self-efficacy beliefs not only relate to teachers' perceptions of their working conditions, job satisfaction, and burnout, but also with student learning and achievement (Caprara et al., 2006; Klassen \& Chiu, 2010; Klassen \& Tze, 2014; Skaalvik \& Skaalvik, 2010).

Teachers' classroom instruction is often seen as an influential lever to directly influence student learning as evidenced in countless educational policy reform aiming for changes in curriculum, pedagogy, and teaching practice. A wide range of research studies support these educational policy reforms through the identification of associations of instructional practices and curriculum designs with differential student outcomes (Desimone et al., 2013; Hattie, 2009, 2012). In particular, some research strands emphasized positive associations of reform-, standards-, or inquiry-based instructional practices with student achievement in the sciences (Bismack et al., 2015; Furtak et al., 2012; Hamilton et al., 2003; Puntambekar et al., 2007; Secker, 2002). In the context of high-school science courses, laboratory investigations represent a common example of such inquiry-based instructional enactments (Abd-El-Khalick et al., 2004; 
National Research Council, 2006). Although a tremendous wealth of research documents the importance of each individual teacher and teaching characteristic to influence student learning and achievement, the research base that comprehensibly evaluates the relationships of this multitude of these teacher-level constructs with student performance on high-stakes examinations in a multi-level framework in the sciences seems underdeveloped.

\section{Importance of Teacher Professional Development for Student Performance}

Many different forms of capacity building can be grouped under the term "professional development," including conventional PD activities (i.e., face-to-face workshops, online courses, and peer-based professional learning communities), as well as informal PD learning opportunities (i.e., one-on-one mentoring/coaching, conference participations, and use of instructional materials such as textbook teacher guides or journal/magazine articles). Theoretical conceptualizations of PD posit that teacher participation in PD can increase teachers' knowledge and skills, which leads to increased confidence in enacting curriculum elements and improved self-efficacy, which can increase the effectiveness of instruction, and subsequently promote positive outcomes in students (Desimone, 2009).

Decades of research on the effectiveness of PD for improving teacher learning (e.g., Banilower et al., 2007; Fishman et al., 2003, p. 20; Garet et al., 2001; Penuel et al., 2007; Saxe et al., 2001) resulted in a consensus of design characteristics that might constitute "high-quality" PD. (Desimone, 2009) summarizes these design characteristics as active learning, coherence, content focus, collective participation, and duration. This summary is similar to other reviews of the PD literature (Borko et al., 2010; Darling-Hammond \& Richardson, 2009; Wilson \& Berne, 1999). The empirical research base on the effectiveness of PD to directly enhance student learning and performance is mixed (Desimone \& Garet, 2015; Kennedy, 2016). Several studies 
indicate positive effects of PD participation on student scores (e.g., Cohen \& Hill, 2000; Fishman et al., 2013; Frumin et al., 2018; Llosa et al., 2016), especially if PD activities have a content focus, model teaching, and/or include active learning components (Gersten et al., 2010; Penuel et al., 2011; Roth et al., 2011; Saxe et al., 2001). However, other studies could not detect positive effects of PD participation on student achievement, even if PD activities are aligned to the highquality PD design characteristics (Garet et al., 2008, 2011; Jacob \& McGovern, 2015). This mixed evidence base for PD effectiveness might evoke questions about the likely impact PD might have on student outcomes in real-world scenarios. Research that systematically identifies potential percentages of student score variation that could be explained with teachers' PD participation might provide a promising novel perspective on this research base.

\section{Research Questions}

This study is connected to a large-scale, multi-methodological, longitudinal National Science Foundation-funded research project that investigates the choice(s) of PD that AP science teachers made and the correlation of teachers' PD with their students' AP science scores. The project takes advantage of an unprecedented opportunity to match student AP scores with teacher and school data for three different science disciplines over time. This paper uses data from this broader study to identify potential levers to increase student performance on high-stakes standardized examinations. This study addresses the following two research questions:

1. How is the variance in students' AP science scores distributed across different conceptual components (i.e., PSAT scores, mothers' educational attainment, school and teacher characteristics, PD participation) at the student- and teacher/school-levels, respectively?

2. What school, teaching, teacher, and teacher PD variables are positively associated with students' AP science scores, after controlling for intractable student characteristics? 


\section{Methods}

\section{Data Sources and Sample}

Data was collected through web-based surveys sent to all AP Biology, AP Chemistry, and AP Physics teachers in the nation (unless placed on a do-not-contact list by the College Board). The surveys asked teachers about their teaching background, classroom instruction, classroom and school context, and attitudes and participation in PD; full survey see Fischer (2017). Response rates ranged from $23 \%$ to $34 \%$, which represents a good response rate for webbased surveys with this population size (Shih \& Fan, 2009). The College Board's data includes information about students' AP and PSAT scores, students' family background, and contextual school and district information.

This study uses data from the second and third year of the AP Biology redesign (2014, 2015) (Year 2: $\mathrm{N}_{\text {teacher }}=1,265, \mathrm{~N}_{\text {student }}=25,108 ;$ Year 3: $\left.\mathrm{N}_{\text {teacher }}=1,243, \mathrm{~N}_{\text {student }}=21,429\right)$, the first two years of the AP Chemistry redesign $(2014,2015)$ (Year 1: $\mathrm{N}_{\text {teacher }}=1,443$, $\mathrm{N}_{\text {student }}=26,449$; Year 2: $\left.\mathrm{N}_{\text {teacher }}=1,219, \mathrm{~N}_{\text {student }}=21,204\right)$, and the first year of the AP Physics redesign $(2015)\left(\mathrm{N}_{\text {teacher }}=876, \mathrm{~N}_{\text {student }}=19,413\right)$. Although the larger study collected data from the first year of the AP Biology redesign, the survey was revised significantly between the first and second/third years, making the first year data substantially less consistent with the analyses in this article. Also, while there is only one form of the AP Biology and AP Chemistry examinations, there are several different forms for AP Physics. We studied only AP Physics 1.

Observations with missing data on variables included in the analysis were removed from the analytical samples. Due to the absence of student-teacher identifiers, only teachers and students in schools with only one AP Biology or one AP Chemistry or one AP Physics 1 teacher were included in the analytical samples. The effect sizes of differences between analytical and 
comparison samples on student performance on PSAT and AP science examinations, as well as the school-level percentage of student enrollment in free- or reduced-priced lunch programs are very small (Table 1). Therefore, analytical samples can be assumed to be a good representation of the entire student and school AP science population in the United States.

\section{[INSERT TABLE 1 ABOUT HERE]}

\section{Measures}

The dependent variable used in these analyses is student achievement as measured through students' scores on the AP Biology, AP Chemistry, and AP Physics examinations. AP scores are measured as ordinal variables with a 1-5 range with 3 considered "passing."

Single-indicator independent variables on the student level include a continuous variable representing students' PSAT scores and a single-indicator ordinal variable describing students' family background as represented by student self-reported on their mothers' educational attainment. On the school-level, variables include a continuous variable describing school affluence as represented by the percentage of students enrolled in free- or reduced-priced lunch programs, and an ordinal variable describing school districts' school support as measured by districts' per-student funding allocations for instructional materials provided by the College Board and based on district and public school record data. On the teacher-level, variables derived from teachers' responses to the web-based surveys include the total hours of AP science course instruction, the number of laboratory investigations, teachers' years of AP teaching experience, teachers' years of experience with the AP redesign, and a 5-point Likert scale rating on teachers' perceived importance of participation in PD activities for students' performance on the AP science exams. In addition, composite independent variables that describe school, teacher, and teaching characteristics derived from teachers' responses to the web-based surveys were 
computed to describe teachers' perceived administrative support, self-efficacy, and enactment of AP redesign practice and curriculum elements (Table 2). These composite variables were computed based on exploratory and confirmatory factor analysis applying Bartlett factor scores, as described in Fischer et al. (2016). Composite independent variables that describe teachers' PD participation include the numbers of conventional PD activities (e.g., summer institutes, one-day workshops, self-paced online courses, College Board's online teacher community, etc.) and informal PD activities (e.g., conferences, one-on-one mentoring, teacher textbook guides, articles from magazines, etc.) in which teachers self-reported their participation in. Additional PD participation variables are inspired by (Desimone, 2009) characteristics of "high quality" PD design characteristics (e.g., 'responsive agenda' refers to Desimone's 'coherence,' 'focus on student work' refers to 'content focus,' relationship building' refers to 'collective participation). Teachers rated their participation for each conventional PD activity on a five-point Likert scale for each Desimone-inspired variable: experience with active learning, responsiveness to teachers' needs and interests, focus on student work or materials from meetings with other teachers, observations of modeled teaching, opportunities to build relationships with colleagues, and effective support for teaching redesigned AP science courses. The analyses utilized the average rating for each Desimone-inspired PD feature across all PDs a teacher participated in. Table 3 describes descriptive information on the dependent and independent variables included in the analyses.

[INSERT TABLE 2 ABOUT HERE]

[INSERT TABLE 3 ABOUT HERE] 


\section{Analytic Methods}

The analyses for this study were conducted in two phases. In the first phase a multilevel ordered logistic regression approach (Hedeker \& Gibbons, 1994; Snijders \& Bosker, 2012) was utilized to examine the associations between student, teacher and school covariates and students' AP science scores. Specifically, for each of the regressions that follow, a proportional odds model was utilized (Agresti, 2002; Hox, 2010). The proportional odds model is the most widely used approach for analyzing multilevel ordinal data. The model assumes that the effect of any given explanatory variable remains constant regardless of the probability of any given level of the outcome. Models were fit for each discipline and year of the AP redesign separately. Modeling was carried out through staging the predictors into the model in blocks using conventional modeling approaches (Hox, 2010). All continuous variables were grand-mean centered to aid in interpretation. The sequence of variables used in the models was as follows: (a) a null model was fitted to the data to establish the percent of variance split between level-1 and level-2 in the model ${ }^{1}$, (b) students' PSAT, (c) mother's highest level of education, (d) teacherand school-level contextual variables, (e) PD characteristic and dosage variables. This modeling sequence emphasizes the variance contribution of teachers' PD participation on students' AP science scores. Model fit for each stage of modeling was compared using the log likelihood ratio test. To answer the first research questions, the percent change in level-2 variance was examined across all models to aid in understanding the variance left unaccounted for by variables in the model.

\footnotetext{
${ }^{1}$ The Intraclass Correlation Coefficient (ICC) statistic was used to calculate the percent of variance split between levels. For ordinal outcomes ICC statistics are calculated as follows: ICC $=\frac{\text { Variance at level }-2}{(\text { Variance at level }-2+(\pi / 3))}$.
} 
In the next phase of modeling, the results were pooled across disciplines and years using meta-regression (i.e., also referred to as a meta-analytic model). This is possible because variables used in all models are identical. The goal with this analysis is to understand the aggregated associations of covariates on students' AP science scores. This meta-regression analysis pools the log odds ratios of the individual multi-level ordered logistic regression analyses across all disciplines and years. The pooled log odds ratios parameters were estimated with a weighted fixed-effects model utilizing restricted maximum-likelihood estimation (Viechtbauer, 2005, 2010, 2016). The applied weights correspond with the sample sizes of each individual study. This analysis does not assume that the true effects are homogenous, but restricts inferences to the sets of models for each discipline and year in the sample. Additionally, Wald tests and confidence intervals were obtained to ascertain the statistical significance of parameters in the model. The statistical significance and confidence intervals are reported for the pooled effect estimate (i.e., $\log (O R))$. Finally, Cochran's Q test for heterogeneity of the effect is reported in order to ascertain if variation between the individual study effects is likely due to factors outside of sampling error (Higgins \& Green, 2011).

\section{Results}

\section{Variance Contributions of Students' AP Science Scores}

Information about the variance components for the models is reported in the form of the Intraclass Correlation Coefficient (ICC) for each model. ICC statistics approximate the average correlation between any two student's test scores within the same classroom. Large ICC statistics indicate that the within-cluster variability is low, and consequently a higher variability between the clusters. High between-cluster variability can be accounted for with student, teacher and school effects, but typically is susceptible to contextual effects (i.e., PD). 
The ICC statistic for students' AP science scores in our data ranges from .37 to .46;

Biology Year 2: .39, Biology Year 3: .37, Chemistry Year 1: .46, Chemistry Year 2: .46, Physics Year 1: .39. This indicates that across all disciplines and years, the within cluster variability is low. This means that $37 \%$ to $46 \%$ of the total variance in students' AP science scores is on the teacher and school-level, whereas the remaining $54 \%$ to $63 \%$ is at the student-level. This is a promising finding because it indicates that students' science performance is not completely predetermined by intractable student-level factors. Instead, a considerable amount of variance could potentially be influenced through educational policy interventions targeted at changes regarding teachers' instructional enactment, as well as teacher- and school-level factors.

In order to identify contributions to the level-2 variance, blocks of covariates were staged into the models (Table 4). The goal with these results is to provide information about the amount of variance remaining in students' AP science scores that could be plausibly contributed by other contextual variables not in the models. Results for the percent of variance accounted for by blocks of covariates indicate that across all models the PSAT scores (i.e., block 1) account for the largest percentage of level-2 variability, accounting for level-2 variance in the range of $28 \%$ to $44 \%$. Students' PSAT scores greatly vary across teachers and schools. Therefore, the inclusion of students' PSAT scores in the model also influences the variance explained at the teacher/school-level despite being a student-level variable (Snijders \& Bosker, 2012). Block 2 examined the addition of maternal educational attainment (another important proximal predictor for student achievement) which only accounted for less than $1 \%$ to $2.3 \%$ of level-2 variance across all disciplines and years. Block 3 examined associations between teacher characteristics and perceptions, as well as school factors on student outcomes. This block of covariates accounts for the second largest percent of level-2 variance in student outcomes; accounting for $11 \%$ to 
$23 \%$ of level-2 variance. The final block of covariates examined were the PD characteristic variables. Overall, this block of covariates has only a small impact on students' AP science scores, accounting for only less than $1 \%$ to $2.3 \%$ of the remaining level-2 variance in students' AP science scores.

[INSERT TABLE 4 ABOUT HERE]

In sum, the results demonstrate that there is substantial variance in students' AP science scores between teachers and schools for all disciplines and years. Whereas PSAT scores and teacher- and school context variables included in the models account for a sizeable portion of the variance in students' AP science scores, the contribution of the included PD characteristics variables only accounted for a comparatively small percentage of level-2 variance. In addition, the remaining unexplained variance on the teacher- and school-level ranges from $40 \%$ to $49 \%$ indicates that there are likely still other contextual variables that our model does not capture that could account for this remaining level-2 variance.

\section{Associations towards Students’ AP Science Scores}

In order to examine the second research question focused on the relationships of school, teaching, teacher, and teacher PD characteristics on students' AP science cores controlling for student characteristics, multilevel ordinal logistic regression analyses were conducted separately for each discipline and year; the parameter estimates, model fit indices, and changes in explained variances for each model are described in the supplementary materials (Supplemental Table S1 - Supplemental Table S5). The present study examined the aggregate effects of each predictor of interest on students' AP science scores combined across all disciplines and years in a meta-analysis. Results for the pooled parameter estimates are reported in Table 5. 


\section{[INSERT TABLE 5 ABOUT HERE]}

Associations with student characteristics. Students' PSAT scores were positively associated with their subsequent AP science scores $(\log (O R)=1.795, S E=0.104, p<0.001)$. In comparison to no post-secondary education, mothers' educational attainment of either a Bachelor's $(\log (O R)=0.134, S E=0.026, p<0.001)$ or graduate degrees $(\log (O R)=0.175$, $S E=0.038, p<0.001)$ also showed positive associations with student's AP science scores. Of these parameter estimates, for the estimated students' PSAT scores, $Q=488.294, p<0.001$, and for mothers with a graduate degree exhibited significant heterogeneity across disciplines and years, $Q=13.716, p<0.001$. This result indicated that the estimated effect sizes likely differed because of factors other than sampling error within the studies.

Associations with school, teacher, and teaching characteristics. Several contextual school-level variables showed significant positive associations with students' AP science scores. Specifically, the percentage of students in schools enrolled in free- or reduced-priced lunch programs was negatively associated with AP science scores, $\log (O R)=-1.917, S E=0.152$, $p<0.001$. This finding aligned with the well-known contributions of SES measures on student performance (e.g., OECD, 2013; Sass et al., 2012) and an expanded discussion of the various ramifications of SES is provided by Crosnoe and Benner (2015). Further, the Cochran's Q statistic indicated that there was significant difference in the estimate generated for each discipline and year, $Q=16.882, p<0.01$. In addition, the administrative support composite (i.e., principal understands challenges for AP science students/teachers, principal supports PD, lighter teaching load/fewer out-of-class responsibilities for AP science teachers, additional funding for AP science, availability of equipment/expendable supplies to perform labs) was significant, and positively associated with students' AP science scores, $\log (O R)=0.032, S E=0.016, p<0.05$. 
Similarly, several variables describing teacher characteristics were significantly associated with students' AP science scores. Teachers' perceived importance of PD for increasing student scores was negatively associated with students' AP science scores, $\log (O R)=-0.061, S E=0.021, p<0.01$, which indicated that teachers who rated this item high have students who performed worse on the AP science exams. Additionally, the self-efficacy composite (i.e., student performance is based on my effort as a teacher, students get better scores due to effective teaching, teaching overcomes inadequate students science backgrounds, and extra teaching effort does not change AP scores) was positively associated with students' AP science scores, $\log (O R)=0.076, S E=0.019, p<0.001$, which indicated that the students of teachers with a high rating on this composite teach performed on average better on the AP science exams. Increases in teachers' years of AP science teaching experience are significantly associated with higher student scores, $\log (O R)=0.021, S E=0.005, p<0.001$. With respect to teachers' instruction, the models indicated several significant associations with student scores. For example, the hours of AP science course instruction students were exposed to was positively associated with students' AP science scores, $\log (O R)=0.029, S E=0.009, p<0.001$. The number of AP labs teachers utilized in their instruction was associated with higher AP science scores, $\log (O R)=0.029, S E=0.009, p<0.001$. Similarly, the enactment of AP practices composite (i.e., students work on laboratory investigations, provide guidance on integrated content questions, provide guidance on open/free response questions, students report laboratory findings to another, students perform inquiry, laboratory investigations, and use science practices outside of the classroom) was positively associated with students' AP science scores, $\log (O R)=0.055, S E=0.018, p<0.01$. However, the enactment of AP curriculum composite (i.e., refer to the "Big Ideas" of science, refer to how enduring understandings relate to the "Big 
Ideas of science, refer to the learning objective from the AP curriculum, refer to the curriculum framework) was negatively associated with students' AP science scores, $\log (O R)=-0.145$, $S E=0.017, p<0.001$.

Associations with PD characteristics. Several of the Desimone-inspired PD characteristic variables based on teachers' self-reported PD quality were significantly associated with students' AP science scores, while other PD variables showed a negative association. Specifically, the Desimone-inspired PD variables characteristics that were negatively associated with students' AP science scores included: teachers' rating regarding the presence of active learning, $\log (O R)=-0.136, S E=0.038, p<0.001$, a focus on student work, $\log (O R)=-0.092$, $S E=0.023, p<0.001$, and modeling teaching $\log (O R)=-0.062, S E=0.025, p<0.05$. Notably, the parameter estimate for active learning varied across disciplines and years, $Q=10.986$, $p<0.05$. Further, the Desimone-inspired PD variables characteristics that were positively associated with students' AP science scores included the teachers' rating regarding the presence of a responsive agenda item, $\log (O R)=0.071, S E=0.028, p<0.05$, and the effectively supporting instruction for the redesigned AP science course item, $\log (O R)=0.149, S E=0.060$, $p<0.05$. The parameter estimate for the PD effectively supporting instruction showed variation across disciplines and years, $Q=13.613, p<0.01$.

\section{Discussion}

\section{Scholarly Significance}

This work is unique in the educational research context in the United States as it constitutes the first science education research study that has had access to national student-, teacher-, school-, and district-level data sets in the midst of a large-scale, top-down mandated science curriculum reform connected to standardized high-stakes examinations across multiple 
science disciplines and years. This study has rare access to a broad spectrum of variables ranging from student scores on nationwide standardized tests to in-depth teacher self-report of participation in more than twenty different PD programs in the landscape of the revised AP Biology, Chemistry, and Physics examinations. This is different from most other research that focuses only on very specific stand-alone high-profile PD programs (Hill, 2015). The structure of the data sets with almost identical variables across different science disciplines and years of the AP redesign afforded the unusual opportunity to utilize a meta-analytic perspective in addition to analyzing each data set individually. The consistency in the outcomes of the statistical models across years and disciplines provides evidence to support the validity and reliability of the findings, providing an uncommon opportunity for research on these important topics in science education. Given the national scope of the data in this study, the findings are likely to be relevant to other large-scale curriculum reforms in the sciences (i.e., Next Generation Science Standards, NGSS Lead States, 2013) and beyond.

\section{Implications and Conclusions}

This study intends to identify levers that might lead to improvements in student learning and achievement in the sciences beyond student characteristics such as prior PSAT score and socioeconomic status. The nationwide samples we analyzed allowed us to identify relationships to student outcomes that were stable over time and across science disciplines. As such, the present study established the variance in students' AP science scores accounted for at the teacher/school-level, which might be potentially amenable to policy changes. Percentages of variance were explained by blocks of variables at the student-, teacher-, and school-level, and relationships of student, school, teaching, teacher, and teacher PD characteristics with students' AP science performance were identified. The hope is to guide school leadership and educational 
policy in science in the mission of improving student performance. The three main findings are the following:

First, student performance is not unchangeably pre-determined by student background characteristics. In particular, the inclusion of well known, influential, and intractable student level factors, i.e., PSAT score and mother's highest level of education (e.g., Ewing et al., 2006; Woessmann, 2004) accounted for $40 \%$ of the variance in students' AP science scores leaving roughly $60 \%$ of the student-level variance unexplained. This supports the examination of associations among school context and teacher characteristics with students' AP science scores, which policy interventions could utilize as levers to improve performance, similarly to what has been reported in several previous research studies (e.g., Kane \& Staiger, 2008; Nye et al., 2004; Papay \& Kraft, 2015; Rivkin et al., 2005; Rockoff, 2004).

Second, several school, teacher, and teaching characteristics were identified that were positively associated with student performance of the AP science examinations. Educational policy interventions could utilize these identified levers in the attempt to increase student learning and achievement. The findings in this study align with prior science education research but those prior studies' findings are more localized and do not have the comprehensive range across science disciplines and time that is available with the data in this study.

School-level factors associated with students' AP science scores included teachers' perceived administrative support. The more teachers feel supported by their principals and other school administrators, the better their students' performance. This is consistent with previous research emphasizing the importance of principals and other school leaders for influencing teachers' work environment, classroom instruction, and ultimately student scores (e.g., Johnson et al., 2012; Kraft et al., 2016; Ladd, 2009; May \& Supovitz, 2011; Supovitz et al., 2010) and 
suggests school leaders should facilitate the creation of supportive work environments for their science teachers.

Teacher-level factors associated with higher student performance on the AP science examinations included teachers' years of AP science teaching experience and perceived selfefficacy, which corresponds with previous research that documents the positive relationships between teacher knowledge and experience, teaching effectiveness, and student performance (e.g., Keller et al., 2017; Nye et al., 2004; Papay \& Kraft, 2015; Wiswall, 2013), as well as research that highlights the importance of teachers' self-efficacy beliefs for instruction and student learning (e.g., Klassen \& Tze, 2014; Tschannen-Moran, Hoy, \& Hoy, 1998).

Teaching-level factors associated with students' AP science scores included the total hours of classroom instruction, the number of laboratory investigations and the enactment of particular practice and curriculum elements of the AP redesign. These findings also mirror previous research that identifies relationships dosage measure for classroom instruction with student performance (e.g., Desimone \& Long, 2010; Marcotte \& Hansen, 2010). A policy recommendation emerging from this is that the total number of instructional hours prior to the AP exam be noted next to AP scores of students. This would, at least, make consumers of AP score data (e.g. college admissions) cognizant of possible instructional disparities that students had no control over. For example, an urban student may only get five class periods per week for AP science while a suburban student may get seven class period per week. This $30 \%$ less instruction could be a reason why the urban student received a 4 instead of a 5 . Also, the positive associations of lab enactments and AP practices align with research that identified relationships emphasizing the importance of teaching and teaching characteristics for student learning and performance (Furtak et al., 2012; Hamilton et al., 2003; Hattie, 2009, 2012; Secker, 2002; Seidel 
\& Shavelson, 2007). The negative association of teachers' enactment of AP curriculum elements (i.e. Big Ideas) seems counterintuitive. This is based on the assumption that an emphasis on Big Ideas as organizing principles for the subject matter content promotes learning. Experts utilize Big Ideas when approaching new problems (National Research Council, 2000). Consensus documents speak to the need for more emphasis on Big Ideas in coursework. (National Research Council, 2012a). That leaves two quite different explanations for this unexpected result. It could be that the teachers answering the questions regarding emphasis on Big Ideas teach these as separate nuggets of information rather than weaving them constantly and consistently through their curriculum. Teachers saying that they don't focus on the Big Ideas may be using them continuously but not setting aside specific times to discuss each Big Idea and isolating it from their instruction of the content. Another possible explanation regards the assessment of knowledge of the Big Ideas. It is possible that the emphasis and importance of Big Ideas is not mirrored adequately in the AP examinations. Observational data would be useful in studying the quality of teacher implementation, but unfortunately was not part of this study design.

Third, the contribution of teachers' PD participation to student achievement is mixed. The addition of Desimone-inspired variables, which describe teachers' perceptions of their PD experiences, only accounted at most for $2.3 \%$ of the level-2 variance in students' AP science scores across all science disciplines and years. However, it is important to note that this study is situated in the context of the AP program. Often, school administrators ask the most experienced and skilled teachers to teach AP courses. Similarly, students taking AP courses and examinations are often among the highest achieving students in their schools. Therefore, this unique population, in contrast to all other students and teachers in the nation, might make detecting additional benefits of teacher PD participation on student achievement more difficult. 
Nonetheless, this finding corresponds with research that describes the mixed evidence base of detecting direct effects of teacher PD participation on student achievement measures, especially for studies that frame PD in terms of Desimone's (2009) list of high-quality PD characteristics (e.g., Desimone \& Garet, 2015; Garet et al., 2008, 2011; Jacob \& McGovern, 2015). While some associations were statistically significant - which might also be in part related to the large sample sizes utilized in the statistical models - the strength of these effects on student science scores is comparatively small, thus, supporting calls for further research on PD effectiveness.

Finally, while the variables included in the models captured a wide range of concepts related to student performance, a substantial percentage of the variance remained in students' scores at the teacher- and school-level. In sum, these results suggested that work still remains in defining theoretically malleable teacher characteristics and behaviors, as well as variables that might serve as additional levers to increase student learning and achievement.

\section{Limitations and Future Work}

The main limitations of this study relate to the data sources. Teacher-level data was limited to teachers' self-reports on the web-based surveys, which might have led to some positive response bias in the responses to survey questions. As a result, parameter estimates might represent upper bounds of plausible associations between many of the teachers' responses to survey items and students' AP science scores. The largest threat to external validity of this study was the absence of student-teacher identifiers. As a result, students could only be matched to the schools, but not to their teachers. In order to safeguard against this threat to validity, a sampling frame was selected by eliminating from the analyses all schools with more than one AP science teacher teaching in the same AP science discipline to uniquely match students with 
teachers. Non-response analyses indicated no notable differences to the wider AP science populations.

Another limitation is that substantial variance at the teacher and school level was not accounted for by the variables included in the models. Future studies should attempt to identify sources of this remaining unexplained variance. For instance, Crosnoe and Benner (2015) outline several additional variables that might affect student science achievement such as school climate, class size, ethnicity, challenging course work, and parental involvement. Additionally relationships between classroom observations and student achievement have been shown to be strong (Kane \& Staiger, 2012). Work on data bases that would allow the separation of teacher and school effects would also be useful. Furthermore, as access to the AP program in schools can be stratified by students' class and race (Klopfenstein, 2004; Klugman, 2013; Schneider, 2009), similar studies with more diverse student and teacher populations should be conducted to examine the robustness of the results of this study. However, it is worth noting that numerous efforts from different stakeholders including the College Board, several U.S. states, and local initiatives have been undertaken to broaden access to the AP program for students who are underprivileged (e.g., Conger, Long, \& Iatarola, 2009; Roegman \& Hatch, 2016; The College Board, 2014). From a methodology perspective, studies that examine relationships of multiple with student performance could investigate more complex associations. The present study utilizes what Opfer and Pedder (2011) describe as process-product logic to identify teacher effects on students' performance. However, many theoretical perspectives used to understand potential levers of educational policy interventions within longer chains of mediational pathways that ultimately lead to increases in student achievement. For example, Desimone's (2009) logic model for the effects of PD relationships indicates that effects of teachers' PD participation on 
student learning and achievement are mediated by teachers' knowledge gains, changes in teachers' belief systems, and teachers' classroom instruction. Therefore, follow-up studies could utilize longitudinal data with a multi-level structural equation modeling approach to examine these mediational pathways. Alternatively, future studies could even further avoid potential oversimplification of the existing interdependent, dynamic, and multidimensional processes in the real world (Cochran-Smith et al., 2014) by identifying potentially malleable levers to improve student performance from a complex systems theory lens (Byrne \& Callaghan, 2014; Lemke \& Sabelli, 2008).

In summary, this study confirms the existence of levers on the teacher and school level to improve student performance as a good deal of variance in student achievement is not affected by student characteristics such as PSAT and SES. Furthermore, these findings were shown to be consistent across disciplines and over time. This provides a strong rationale for the continued efforts of policy makers to improve school environments and support the science teachers that work in them. It appears likely that there are variables within the educational system that can be modified to overcome existing inequities in science achievement and help all students graduate prepared for college and ready for future careers. 


\section{References}

Abd-El-Khalick, F., BouJaoude, S., Duschl, R., Lederman, N. G., Mamlok-Naaman, R., Hofstein, A., Niaz, M., Treagust, D., \& Tuan, H. (2004). Inquiry in science education: International perspectives. Science Education, 88(3), 397-419. https://doi.org/10.1002/sce.10118

Agresti, A. (2002). Categorical data analysis (2nd ed.). Wiley-Interscience.

Atkinson, R. C., \& Geiser, S. (2009). Reflections on a century of college admissions tests. Educational Researcher, 38(9), 665-676. https://doi.org/10.3102/0013189X09351981

Banilower, E. R., Heck, D. J., \& Weiss, I. R. (2007). Can professional development make the vision of the standards a reality? The impact of the National Science Foundation's local systemic change through teacher enhancement initiative. Journal of Research in Science Teaching, 44(3), 375-395. https://doi.org/10.1002/tea.20145

Bismack, A. S., Arias, A. M., Davis, E. A., \& Palincsar, A. S. (2015). Examining student work for evidence of teacher uptake of educative curriculum materials. Journal of Research in Science Teaching, 52(6), 816-846. https://doi.org/10.1002/tea.21220

Borko, H., Jacobs, J., \& Koellner, K. (2010). Contemporary approaches to teacher professional development. In P. Peterson, E. Baker, \& B. McGaw (Eds.), International encyclopedia of education (pp. 548-556). Elsevier.

Boyd, D., Grossman, P. L., Hammerness, K., Lankford, R. H., Loeb, S., McDonald, M., Reininger, M., Ronfeldt, M., \& Wyckoff, J. (2008). Surveying the landscape of teacher education in New York City: Constrained variation and the challenge of innovation. Educational Evaluation and Policy Analysis, 30(4), 319-343. https://doi.org/10.3102/0162373708322737 
Brault, M.-C., Janosz, M., \& Archambault, I. (2014). Effects of school composition and school climate on teacher expectations of students: A multilevel analysis. Teaching and Teacher Education, 44, 148-159. https://doi.org/10.1016/j.tate.2014.08.008

Buehl, M. M., \& Fives, H. (2016). The role of epistemic cognition in teacher learning and praxis. In J. A. Greene, W. A. Sandoval, \& I. Braten (Eds.), Handbook of epistemic cognition (pp. 247-264). Routledge.

Byrne, D., \& Callaghan, G. (2014). Complexity theory and the social sciences: The state of the art. Routledge.

Caprara, G. V., Barbaranelli, C., Steca, P., \& Malone, P. S. (2006). Teachers’ self-efficacy beliefs as determinants of job satisfaction and students' academic achievement: A study at the school level. Journal of School Psychology, 44(6), 473-490. https://doi.org/10.1016/j.jsp.2006.09.001

Chen, X. (2013). STEM attrition: College students' paths into and out of STEM fields (Statistical Analysis Report NCES 2014-001). National Center for Education Statistics, Institute of Education Sciences, U.S. Department of Education.

Cochran-Smith, M., Ell, F., Ludlow, L., Grudnoff, L., \& Aitken, G. (2014). The challenge and promise of complexity theory for teacher education research. Teachers College Record, $116(5), 1-38$.

Cohen, D. K., \& Ball, D. L. (1999). Instruction, capacity, and improvement (RR-43; CPRE Research Report Series). University of Pennsylvania, Consortium for Policy Research in Education.

Cohen, D. K., \& Hill, H. C. (2000). Instructional policy and classroom performance: The mathematics reform in California. Teachers College Record, 102(2), 294-343. 
Conger, D., Long, M. C., \& Iatarola, P. (2009). Explaining race, poverty, and gender disparities in advanced course-taking. Journal of Policy Analysis and Management, 28(4), 555-576. https://doi.org/10.1002/pam.20455

Cromwell, A., McClarty, K. L., \& Larson, S. J. (2013). College readiness indicators. Bulletin, 25, $1-8$.

Crosnoe, R. (2009). Low-income students and the socioeconomic composition of public high schools. American Sociological Review, 74(5), 709-730.

Crosnoe, R., \& Benner, A. D. (2015). Children at school. In R. M. Lerner (Ed.), Handbook on child psychology and developmental science (Vol. 4, pp. 268-304). Wiley.

Daly, A. J., Moolenaar, N. M., Der-Martirosian, C., \& Liou, Y.-H. (2014). Accessing capital resources: Investigating the effects of teacher human and social capital on student achievement. Teachers College Record, 116(7), 070302.

Darling-Hammond, L., \& Richardson, N. (2009). Research review / Teacher learning: What matters? Educational Leadership, 66(5), 46-53.

Davis-Kean, P. E. (2005). The influence of parent education and family income on child achievement: The indirect role of parental expectations and the home environment. Journal of Family Psychology, 19(2), 294-304. https://doi.org/10.1037/08933200.19.2.294

Desforges, C., \& Abouchaar, A. (2003). The impact of parental involvement, parental support and family education on pupil achievement and adjustment: A literature review (Research Report RR433). Department for Education and Skills.

Desimone, L. (2009). Improving impact studies of teachers' professional development: Toward better conceptualizations and measures. Educational Researcher, 38(3), 181-199. 
https://doi.org/10.3102/0013189X08331140

Desimone, L., \& Garet, M. S. (2015). Best practices in teachers' professional development in the United States. Psychology, Society and Education, 7(3), 252-263. https://doi.org/10.25115/psye.v7i3.515

Desimone, L., \& Long, D. (2010). Teacher effects and the achievement gap: Do teacher and teaching quality influence the achievement gap between Black and White and high-and low-SES students in the early grades. Teachers College Record, 112(12), 3024-3073.

Desimone, L., Smith, T. M., \& Phillips, K. (2013). Linking student achievement growth to professional development participation and changes in instruction: A longitudinal study of elementary students and teachers in Title I schools. Teachers College Record, 115(5), $1-46$.

Ewing, M., Camara, W. J., \& Millsap, R. E. (2006). The relationship between PSAT/NMSQT scores and AP examination grades: A follow-up study. The College Board.

Ewing, M., Huff, K., \& Kaliski, P. (2010). Validating AP exam scores. Current research and new directions. In P. M. Sadler, G. Sonnert, R. H. Tai, \& K. Klopfenstein (Eds.), AP: A critical examination of the Advanced Placement program (pp. 85-105). Harvard Education Press.

Fischer, C. (2017). Examining forms and frames for science teacher learning related to largescale reforms: A multi-manuscript dissertation [Doctoral Thesis]. University of Michigan.

Fischer, C., Fishman, B., Dede, C., Eisenkraft, A., Frumin, K., Foster, B., Lawrenz, F., Levy, A. J., \& McCoy, A. (2018). Investigating relationships between school context, teacher professional development, teaching practices, and student achievement in response to a 
nationwide science reform. Teaching and Teacher Education, 72, 107-121. https://doi.org/10.1016/j.tate.2018.02.011

Fischer, C., Fishman, B., Levy, A., Eisenkraft, A., Dede, C., Lawrenz, F., Jia, Y., Kook, J., Frumin, K., \& McCoy, A. (2016). When do students in low-SES schools perform betterthan-expected on a high-stakes test? Analyzing school, teacher, teaching, and professional development characteristics. Urban Education, OnlineFirst. https://doi.org/10.1177/0042085916668953

Fishman, B., Konstantopoulos, S., Kubitskey, B. W., Vath, R., Park, G., Johnson, H., \& Edelson, D. C. (2013). Comparing the impact of online and face-to-face professional development in the context of curriculum implementation. Journal of Teacher Education, 64(5), 426438.

Fishman, B., Marx, R. W., Best, S., \& Tal, R. T. (2003). Linking teacher and student learning to improve professional development in systemic reform. Teaching and Teacher Education, 19(6), 643-658. https://doi.org/10.1016/S0742-051X(03)00059-3

Fives, H., \& Buehl, M. M. (2012). Spring cleaning for the "messy" construct of teachers' beliefs: What are they? Which have been examined? What can they tell us? In K. R. Harris, S. Graham, T. Urdan, S. Graham, J. M. Royer, \& M. Zeidner (Eds.), APA educational psychology handbook (Vol. 2, pp. 471-499). American Psychological Association.

Fives, H., \& Buehl, M. M. (2016). Teachers' beliefs, in the context of policy reform. Policy Insights from the Behavioral and Brain Sciences, 3(1), 114-121.

Frumin, K., Dede, C., Fischer, C., Foster, B., Lawrenz, F., Eisenkraft, A., Fishman, B., Jurist Levy, A., \& McCoy, A. (2018). Adapting to large-scale changes in Advanced Placement Biology, Chemistry, and Physics: The impact of online teacher communities. 
International Journal of Science Education, 40(4), 397-420.

https://doi.org/10.1080/09500693.2018.1424962

Furtak, E. M., Seidel, T., Iverson, H., \& Briggs, D. C. (2012). Experimental and quasiexperimental studies of inquiry-based science teaching: A meta-analysis. Review of Educational Research, 82(3), 300-329. https://doi.org/10.3102/0034654312457206

Garet, M. S., Cronen, S., Eaton, M., Kurki, A., Ludwig, M., Jones, W., Uekawa, K., Falk, A., Bloom, H. S., Doolittle, F., Zhu, P., \& Sztejnberg, L. (2008). The impact of two professional development interventions on early reading Instruction and achievement (NCEE 2008-4030). National Center for Education Evaluation and Regional Assistance, Institute of Education Sciences, U.S. Department of Education.

Garet, M. S., Porter, A. C., Desimone, L., Birman, B. F., \& Yoon, K. S. (2001). What makes professional development effective? Results from a national sample of teachers. American Educational Research Journal, 38(4), 915-945. https://doi.org/10.3102/00028312038004915

Garet, M. S., Wayne, A. J., Stancavage, F., Taylor, J., Eaton, M., Walters, K., Song, M., Brown, S., Hurlburt, S., Zhu, P., Sepanik, S., \& Doolittle, F. (2011). Middle school mathematics professional development impact study: Findings after the second year of implementation (NCEE 2011-4024). National Center for Education Evaluation and Regional Assistance, Institute of Education Sciences, U.S. Department of Education.

Gersten, R., Dimino, J., Jayanthi, M., Kim, J. S., \& Santoro, L. E. (2010). Teacher study group: Impact of the professional development model on reading instruction and student outcomes in first grade classrooms. American Educational Research Journal, 47(3), 694739. https://doi.org/10.3102/0002831209361208 
Hamilton, L. S., McCaffrey, D. F., Stecher, B. M., Klein, S. P., Robyn, A., \& Bugliari, D. (2003). Studying large-scale reforms of instructional practice: An example from mathematics and science. Educational Evaluation and Policy Analysis, 25(1), 1-29. https://doi.org/10.3102/01623737025001001

Hattie, J. (2009). Visible learning: A synthesis of over 800 meta-analyses relating to achievement. Routledge.

Hattie, J. (2012). Visible learning for teachers: Maximizing impact on learning. Routledge.

Hedeker, D., \& Gibbons, R. D. (1994). A random-effects ordinal regression model for multilevel analysis. Biometrics, 50(4), 933. https://doi.org/10.2307/2533433

Higgins, J., \& Green, S. (2011). Cochrane handbook for systematic reviews of interventions (4th ed.). John Wiley \& Sons.

Hill, H. C. (2015). Review of the mirage: Confronting the hard truth about our quest for teacher development. National Education Policy Center. http://www.greatlakescenter.org/docs/Think_Twice/TT-Hill-TNTP.pdf

Hox, J. J. (2010). Multilevel analysis: Techniques and applications (2nd ed.). Routledge.

Jackson, C. K., Rockoff, J. E., \& Staiger, D. O. (2014). Teacher effects and teacher-related policies. Annual Review of Economics, 6(1), 801-825. https://doi.org/10.1146/annureveconomics-080213-040845

Jacob, A., \& McGovern, K. (2015). The Mirage: Confronting the hard truth about our quest for teacher development. The New Teacher Project.

Johnson, S. M., Kraft, M. A., \& Papay, J. P. (2012). How context matters in high-need schools: The effects of teachers' working conditions on their professional satisfaction and their students' achievement. Teachers College Record, 114(10), 1-39. 
Kane, T. J., \& Staiger, D. O. (2008). Estimating teacher impacts on student achievement: An experimental evaluation. National Bureau of Economic Research.

Kane, T. J., \& Staiger, D. O. (2012). Gathering feedback for teaching: Combining high-quality observations with student surveys and achievement gains (MET Project.) [Research Paper]. Bill \& Melinda Gates Foundation. http://eric.ed.gov/?id=ED540960

Keller, M. M., Neumann, K., \& Fischer, H. E. (2017). The impact of physics teachers' pedagogical content knowledge and motivation on students' achievement and interest. Journal of Research in Science Teaching, 54(5), 586-614. https://doi.org/10.1002/tea.21378

Kena, G., Hussar, W., McFarland, J., de Brey, C., Musu-Gillette, L., Wang, X., Zhang, J., Rathbun, A., Wilkinson-Flicker, S., Diliberti, M., Barmer, A., Bullock Mann, F., \& Dunlop Velez, E. (2016). The condition of education 2016 (NCES 2016-144). U.S. Department of Education, National Center for Education Statistics.

Kennedy, M. M. (2016). How does professional development improve teaching? Review of Educational Research, 86(4), 945-980. https://doi.org/10.3102/0034654315626800

Klassen, R. M., \& Chiu, M. M. (2010). Effects on teachers' self-efficacy and job satisfaction: Teacher gender, years of experience, and job stress. Journal of Educational Psychology, 102(3), 741-756. https://doi.org/10.1037/a0019237

Klassen, R. M., \& Tze, V. M. C. (2014). Teachers' self-efficacy, personality, and teaching effectiveness: A meta-analysis. Educational Research Review, 12, 59-76. https://doi.org/10.1016/j.edurev.2014.06.001

Klopfenstein, K. (2004). Advanced Placement: Do minorities have equal opportunity? Economics of Education Review, 23(2), 115-131. 
Klugman, J. (2013). The Advanced Placement arms race and the reproduction of educational inequality. Teachers College Record, 115(5), 1-34.

Kraft, M. A., Marinell, W. H., \& Shen-Wei Yee, D. (2016). School organizational contexts, teacher turnover, and student achievement: Evidence from panel data. American Educational Research Journal, 53(5), 1411-1449.

https://doi.org/10.3102/0002831216667478

Ladd, H. F. (2009). Teachers' perceptions of their working conditions: How predictive of policyrelevant outcomes? (Working Paper 33). Center for the Analysis of Longitudinal Data in Education Research.

Leithwood, K., Seashore, K., Anderson, S., \& Wahlstrom, K. (2004). Review of research: How leadership influences student learning [Executive Summary]. University of Minnesota, Center for Applied Research and Educational Improvement.

Lemke, J. K., \& Sabelli, N. H. (2008). Complex systems and educational change: Towards a new research agenda. In M. Mason (Ed.), Complexity theory and the philosophy of education (pp. 112-123). Wiley-Blackwell.

Llosa, L., Lee, O., Jiang, F., Haas, A., OConnor, C., Van Booven, C. D., \& Kieffer, M. J. (2016). Impact of a large-scale science intervention focused on English Language Learners. American Educational Research Journal, 53(2), 395-424. https://doi.org/10.3102/0002831216637348

Marcotte, D. E., \& Hansen, B. (2010). Time for school. Education Next, 10(1), 52-59.

May, H., \& Supovitz, J. A. (2011). The scope of principal efforts to improve instruction. Educational Administration Quarterly, 47(2), 332-352. https://doi.org/10.1177/0013161X10383411 
National Academy of Sciences, National Academy of Engineering, \& Institute of Medicine. (2007). Rising above the gathering storm: Energizing and employing America for a brighter economic future. National Academies Press.

National Research Council. (2000). How people learn: Brain, mind, experience, and school. National Academies Press.

National Research Council. (2002). Learning and understanding: Improving advanced study of mathematics and science in U.S. high schools. National Academies Press.

National Research Council. (2005). How students learn: History, mathematics, and science in the classroom. National Academies Press.

National Research Council. (2006). America's lab report: Investigations in high school science. National Academies Press.

National Research Council. (2012a). A framework for K-12 science education: Practices, crosscutting concepts, and core ideas. National Academies Press.

National Research Council. (2012b). Education for life and work: Developing transferable knowledge and skills in the 21st century. National Academies Press.

National Student Clearninghouse. (2017). The role of community colleges in postsecondary success (No. 0117-0). National Student Clearninghouse Research Center.

NGSS Lead States. (2013). Next generation science standards: For states, by states. Achieve, Inc. On behalf of the twenty-six states and partners that collaborated on the NGSS.

Nye, B., Konstantopoulos, S., \& Hedges, L. V. (2004). How large are teacher effects? Educational Evaluation and Policy Analysis, 26(3), 237-257. https://doi.org/10.3102/01623737026003237

OECD. (2013). Country note. Results from PISA 2012. United States. OECD Publishing. 
Opfer, V. D., \& Pedder, D. (2011). Conceptualizing teacher professional learning. Review of Educational Research, 81(3), 376-407. https://doi.org/10.3102/0034654311413609

Ost, B. (2014). How do teachers improve? The relative importance of specific and general human capital. American Economic Journal: Applied Economics, 6(2), 127-151. https://doi.org/10.1257/app.6.2.127

Palardy, G. J. (2013). High school socioeconomic segregation and student attainment. American Educational Research Journal, 50(4), 714-754. https://doi.org/10.3102/0002831213481240

Papay, J. P., \& Kraft, M. A. (2015). Productivity returns to experience in the teacher labor market: Methodological challenges and new evidence on long-term career improvement. Journal of Public Economics, 130, 105-119. https://doi.org/10.1016/j.jpubeco.2015.02.008

Penuel, W. R., Fishman, B., Yamaguchi, R., \& Gallagher, L. P. (2007). What makes professional development effective? Strategies that foster curriculum implementation. American Educational Research Journal, 44(4), 921-958.

Penuel, W. R., Gallagher, L. P., \& Moorthy, S. (2011). Preparing teachers to design sequences of instruction in earth systems science: A comparison of three professional development programs. American Educational Research Journal, 48(4), 996-1025. https://doi.org/10.3102/0002831211410864

Puntambekar, S., Stylianou, A., \& Goldstein, J. (2007). Comparing classroom enactments of an inquiry curriculum: Lessons learned from two teachers. Journal of the Learning Sciences, 16(1), 81-130. https://doi.org/10.1080/10508400709336943

Rivkin, S. G., Hanushek, E. A., \& Kain, J. F. (2005). Teachers, schools, and academic 
achievement. Econometrica, 73(2), 417-458. https://doi.org/10.1111/j.14680262.2005.00584.x

Rockoff, J. E. (2004). The impact of individual teachers on student achievement: Evidence from panel data. The American Economic Review, 94(2), 247-252.

Roegman, R., \& Hatch, T. (2016). The AP lever for boosting access, success, and equity. Phi Delta Kappan, 97(5), 20-25.

Roth, K. J., Garnier, H. E., Chen, C., Lemmens, M., Schwille, K., \& Wickler, N. I. Z. (2011). Videobased lesson analysis: Effective science PD for teacher and student learning. Journal of Research in Science Teaching, 48(2), 117-148. https://doi.org/10.1002/tea.20408

Rothstein, J. M. (2004). College performance predictions and the SAT. Journal of Econometrics, 121(1-2), 297-317. https://doi.org/10.1016/j.jeconom.2003.10.003

Sass, T. R., Hannaway, J., Xu, Z., Figlio, D. N., \& Feng, L. (2012). Value added of teachers in high-poverty schools and lower poverty schools. Journal of Urban Economics, 72(2-3), 104-122. https://doi.org/10.1016/j.jue.2012.04.004

Saxe, G. B., Gearhart, M., \& Nasir, N. S. (2001). Enhancing students' understanding of mathematics: A study of three contrasting approaches to professional support. Journal of Mathematics Teacher Education, 4(1), 55-79.

Schneider, J. (2009). Privilege, equity, and the Advanced Placement program: Tug of war. Journal of Curriculum Studies, 41(6), 813-831. https://doi.org/10.1080/00220270802713613

Secker, C. von. (2002). Effects of inquiry-based teacher practices on science excellence and equity. The Journal of Educational Research, 95(3), 151-160. 
https://doi.org/10.1080/00220670209596585

Seidel, T., \& Shavelson, R. J. (2007). Teaching effectiveness research in the past decade: The role of theory and research design in disentangling meta-analysis results. Review of Educational Research, 77(4), 454-499. https://doi.org/10.3102/0034654307310317

Shih, T.-H., \& Fan, X. (2009). Comparing response rates in e-mail and paper surveys: A metaanalysis. Educational Research Review, 4(1), 26-40. https://doi.org/10.1016/j.edurev.2008.01.003

Shulman, L. S. (1986). Those who understand: Knowledge growth in teaching. Educational Researcher, 15(2), 4-14. https://doi.org/10.2307/1175860

Skaalvik, E. M., \& Skaalvik, S. (2010). Teacher self-efficacy and teacher burnout: A study of relations. Teaching and Teacher Education, 26(4), 1059-1069. https://doi.org/10.1016/j.tate.2009.11.001

Snijders, T. A. B., \& Bosker, R. J. (2012). Multilevel analysis: An Introduction to basic and applied multilevel analysis (2nd ed.). SAGE.

Supovitz, J. A., Sirinides, P., \& May, H. (2010). How principals and peers influence teaching and learning. Educational Administration Quarterly, 46(1), 31-56. https://doi.org/10.1177/1094670509353043

Supovitz, J. A., \& Turner, H. M. (2000). The effects of professional development on science teaching practices and classroom culture. Journal of Research in Science Teaching, 37(9), 963-980.

Teodorović, J. (2011). Classroom and school factors related to student achievement: What works for students? School Effectiveness and School Improvement, 22(2), 215-236. https://doi.org/10.1080/09243453.2011.575650 
The College Board. (2014). The 10th annual AP report to the nation. The College Board.

Tschannen-Moran, M., Hoy, A. W., \& Hoy, W. K. (1998). Teacher efficacy: Its meaning and measure. Review of Educational Research, 68(2), 202-248.

van Geel, M., Keuning, T., Visscher, A. J., \& Fox, J.-P. (2016). Assessing the effects of a school-wide data-based decision-making intervention on student achievement growth in primary schools. American Educational Research Journal, 53(2), 360-394. https://doi.org/10.3102/0002831216637346

Veal, W. R., Riley Lloyd, M. E., Howell, M. R., \& Peters, J. (2016). Normative beliefs, discursive claims, and implementation of reform-based science standards. Journal of Research in Science Teaching, 53(9), 1419-1443. https://doi.org/10.1002/tea.21265

Viechtbauer, W. (2005). Bias and efficiency of meta-analytic variance estimators in the randomeffects model. Journal of Educational and Behavioral Statistics, 30(3), 261-293.

Viechtbauer, W. (2010). Conducting meta-analyses in R with the metafor package. Journal of Statistical Software, 36(3), 1-48.

Viechtbauer, W. (2016). Meta-analysis package for $R$ [R]. http://www.metafor-project.org/

Waters, T., Marzano, R. J., \& McNulty, B. (2003). Balanced leadership: What 30 years of research tells us about the effect of leadership on student achievement. A working paper. Mid-Continent Regional Educational Lab.

Willms, J. D. (2010). School composition and contextual effects on student outcomes. Teachers College Record, 112(4), 1008-1037.

Wilson, S. M., \& Berne, J. (1999). Teacher learning and the acquisition of professional knowledge: An examination of research on contemporary professional development. Review of Research in Education, 24(1), 173-209. 
Wiswall, M. (2013). The dynamics of teacher quality. Journal of Public Economics, 100, 61-78. https://doi.org/10.1016/j.jpubeco.2013.01.006

Woessmann, L. (2004). How equal are educational opportunities? Family background and student achievement in Europe and the US (CESIFO Working Paper No. 1162). Ifo Institute for Economic Research.

Zhang, X., Patel, P., \& Ewing, M. (2014). AP® Potential predicted by PSAT/NMSQT® scores using logistic regression (Statistical Report 2014-1). The College Board. 


\section{Tables}

Table 1. Non-response analysis.

\begin{tabular}{|c|c|c|c|}
\hline & $z$ & $p$ & $r$ \\
\hline \multicolumn{4}{|c|}{ Students' PSAT scores } \\
\hline Biology Year 2 & 6.036 & $<0.001$ & 0.015 \\
\hline Biology Year 3 & 5.436 & $<0.001$ & 0.013 \\
\hline Chemistry Year 1 & 2.898 & $<0.001$ & 0.009 \\
\hline Chemistry Year 2 & 7.407 & $<0.001$ & 0.022 \\
\hline Physics Year 1 & 8.003 & $<0.001$ & 0.022 \\
\hline \multicolumn{4}{|c|}{ Students' AP scores } \\
\hline Biology Year 2 & -22.164 & $<0.001$ & 0.050 \\
\hline Biology Year 3 & -19.190 & $<0.001$ & 0.042 \\
\hline Chemistry Year 1 & -25.728 & $<0.001$ & 0.072 \\
\hline Chemistry Year 2 & -16.093 & $<0.001$ & 0.043 \\
\hline Physics Year 1 & -8.475 & $<0.001$ & 0.022 \\
\hline \multicolumn{4}{|c|}{ Percentage free- or reduced-priced lunch programs } \\
\hline Biology Year 2 & -8.088 & $<0.001$ & 0.089 \\
\hline Biology Year 3 & -9.327 & $<0.001$ & 0.101 \\
\hline Chemistry Year 1 & -9.670 & $<0.001$ & 0.122 \\
\hline Chemistry Year 2 & -8.695 & $<0.001$ & 0.106 \\
\hline Physics Year 1 & -8.792 & $<0.001$ & 0.132 \\
\hline
\end{tabular}


Table 2. Variables included in computations of composite variables

\author{
Included variables
}

Administrative (a) Principal understands challenges for AP science students ${ }^{\times}$, (b) principal understands

support challenges for AP science teachers ${ }^{\times}$, (c) principal supports PD $^{\times}$, (d) lighter teaching load for AP science teachers $^{\times}$, (e) fewer out-of-class responsibilities for AP science teachers ${ }^{\times}$, (f) AP science is given additional funding $\times$, (g) availability of equipment to perform labs ${ }^{\diamond},(\mathrm{h})$ availability of expendable (consumable) supplies to perform labs ${ }^{\diamond}$

Enactment: AP (a) Students work on laboratory investigations ${ }^{\times}$, (b) provide guidance on integrated content practices questions ${ }^{\times}$, (c) provide guidance on open/free response questions ${ }^{\times}$, (d) students report laboratory findings to another ${ }^{\times}$, (e) students perform inquiry laboratory investigations ${ }^{\times}$

Enactment: AP (a) Refer to the "Big Ideas"”, (b) use science practices outside of the classroom", (c) refer how curriculum enduring understandings relate to the "Big Ideas ${ }^{\times}$," (d) refer to learning objectives from AP curriculum $^{\times},(\mathrm{e})$ refer to the curriculum framework ${ }^{\times}$

Self-efficacy (a) Students perform better because of my extra effort ${ }^{\times}$, (b) student scores improve because of my teaching $\times$, (c) my teaching can overcome student backgrounds ${ }^{\times}$, (d) extra effort in teaching produces little change ${ }^{x}$

Number / Face-to-face: AP Summer Institute ${ }^{\mathrm{CB}}$, AP Fall Workshop ${ }^{\mathrm{CB}}$, transition to inquiry-based labs Duration of conventional

PD activities ${ }^{\square} \quad$ Online courses: Transition to inquiry labs ${ }^{\mathrm{CB}}$, Introduction to AP Biology/Chemistry/Physics ${ }^{\mathrm{CB}}$, workshop $^{\mathrm{CB}}$, Day with AP reader ${ }^{\mathrm{CB}}$, laying the foundation by NMSI, BSCS Leadership Academy by BSCS and NABT, reasoning skills workshop ${ }^{\mathrm{CB}}$ AP Central webcast - Exploring atomic structure using photoelectron spectroscopy ${ }^{\mathrm{CB}}$, AP insight $^{\mathrm{CB}}$

Online communities: AP online teacher community ${ }^{\mathrm{CB}}$, NSTA online teacher community

Number of Face-to-face: District/regional/local college/teacher-initiated meetings, mentoring/coaching oneunconventional on-one or with other teachers, conference or conference sessions, Serving as AP exam reader, PD activities ${ }^{\square} \quad$ Serving as AP consultant

Materials: AP course and exam description ${ }^{\mathrm{CB}}, \mathrm{AP}$ lab manual ${ }^{\mathrm{CB}}$, teacher textbook guide and related materials, student guide: data analysis ${ }^{\mathrm{CB}}$, teacher guide: quantitative skills and analysis ${ }^{\mathrm{CB}}$, AP practice exams, materials developed from colleagues, articles from magazines/journals, video resources, computer-based simulations

Note. ${ }^{\square}$ : Teachers were not asked to indicate their participation on all listed PD activities for each discipline and year, ${ }^{\times}: 5$-point Likert scale item, ${ }^{\diamond}: 4$-point Likert scale item, ${ }^{\mathrm{CB}}$ : provided by the College Board. 
Table 3. Descriptive information of variables used in analyses.

\begin{tabular}{|c|c|c|c|c|c|c|c|c|c|c|}
\hline & \multicolumn{2}{|c|}{ Biology Y2 } & \multicolumn{2}{|c|}{ Biology Y3 } & \multicolumn{2}{|c|}{ Chemistry Y1 } & \multicolumn{2}{|c|}{ Chemistry Y2 } & \multicolumn{2}{|c|}{ Physics Y1 } \\
\hline & $\begin{array}{c}\mathrm{N} / \\
\text { Mean }\end{array}$ & $\begin{array}{c}\% / \\
(\mathrm{SD})\end{array}$ & $\begin{array}{c}\mathrm{N} / \\
\text { Mean }\end{array}$ & $\begin{array}{l}\% / \\
(\mathrm{SD})\end{array}$ & $\begin{array}{c}\mathrm{N} / \\
\text { Mean }\end{array}$ & $\begin{array}{l}\% / \\
\text { (SD) }\end{array}$ & $\begin{array}{c}\mathrm{N} / \\
\text { Mean }\end{array}$ & $\begin{array}{l}\% / \\
\text { (SD) }\end{array}$ & $\begin{array}{c}\mathrm{N} / \\
\text { Mean }\end{array}$ & $\begin{array}{l}\% / \\
(\mathrm{SD})\end{array}$ \\
\hline \multicolumn{11}{|c|}{ Dependent variable } \\
\hline \multicolumn{11}{|l|}{ AP Score } \\
\hline 1 & 1,564 & 6.23 & 1,105 & 5.16 & 4,243 & 16.04 & 3,804 & 17.94 & 5,739 & 29.56 \\
\hline 2 & 6,053 & 24.11 & 5,418 & 25.28 & 6,800 & 25.71 & 5,325 & 25.11 & 5,946 & 30.63 \\
\hline 3 & 9,102 & 36.25 & 8,069 & 37.65 & 7,394 & 27.96 & 6,335 & 29.88 & 4,115 & 21.20 \\
\hline 4 & 6,379 & 25.41 & 5,231 & 24.41 & 4,961 & 18.76 & 3,721 & 17.55 & 2,716 & 13.99 \\
\hline 5 & 2,010 & 8.01 & 1,606 & 7.49 & 3,051 & 11.54 & 2,019 & 9.52 & 897 & 4.62 \\
\hline \multicolumn{11}{|c|}{ Student Characteristics } \\
\hline PSAT scores & 164.2 & $(26.8)$ & 163.3 & (26.5) & 173.4 & $(26.8)$ & 172.2 & $(26.8)$ & 167.1 & (26.4) \\
\hline \multicolumn{11}{|c|}{ Mothers' educational attainment } \\
\hline No post-secondary & 4,765 & 18.98 & 4,180 & 19.51 & 4,345 & 16.43 & 3,562 & 16.80 & 3,771 & 19.43 \\
\hline Some post-secondary & 5,742 & 22.87 & 4,770 & 22.26 & 5,420 & 20.49 & 4,305 & 20.30 & 4,169 & 21.48 \\
\hline Bachelor's degree & 8,210 & 32.70 & 6,895 & 32.18 & 9,163 & 34.64 & 7,202 & 33.97 & 6,555 & 33.77 \\
\hline Graduate degree & 6,391 & 25.45 & 5,584 & 26.06 & 7,521 & 28.44 & 6,135 & 28.93 & 4,918 & 25.33 \\
\hline \multicolumn{11}{|c|}{ School Characteristics } \\
\hline $\begin{array}{l}\text { Percentage free- or } \\
\text { reduced lunch }\end{array}$ & 33.6 & $(22.8)$ & 37.6 & $(23.2)$ & 31.3 & $(22.0)$ & 34.3 & $(22.1)$ & 36.7 & (21.9) \\
\hline District-funding for inst & ional $\mathrm{m}$ & terials & & & & & & & & \\
\hline Funding $<\$ 200$ & 600 & 47.43 & 589 & 47.39 & 669 & 46.36 & 519 & 42.58 & 422 & 48.17 \\
\hline Funding $\$ 200-\$ 300$ & 434 & 34.31 & 435 & 35.00 & 474 & 32.85 & 463 & 37.98 & 288 & 32.88 \\
\hline Funding $>\$ 300$ & 231 & 18.26 & 219 & 17.62 & 300 & 20.79 & 237 & 19.44 & 166 & 18.95 \\
\hline \multicolumn{11}{|c|}{ Teacher and Teaching Characteristics } \\
\hline Administrative support & -0.07 & $(1.09)$ & -0.10 & $(1.09)$ & -0.11 & $(1.09)$ & -0.10 & $(1.11)$ & -0.08 & (1.10) \\
\hline $\begin{array}{l}\text { Hours of AP instruction } \\
\text { (in } 10 \mathrm{~h} \text { ) }\end{array}$ & 17.90 & $(5.51)$ & 17.74 & $(5.49)$ & 17.51 & $(5.39)$ & 17.14 & $(5.33)$ & 15.92 & $(4.39)$ \\
\hline $\begin{array}{l}\text { Enactment of AP } \\
\text { curriculum elements }\end{array}$ & 0.03 & $(1.10)$ & 0.05 & (1.11) & 0.03 & $(1.08)$ & 0.04 & $(1.05)$ & 0.04 & $(1.05)$ \\
\hline $\begin{array}{l}\text { Enactment of AP } \\
\text { practice elements }\end{array}$ & 0.03 & (1.17) & 0.03 & $(1.15)$ & -0.01 & $(1.16)$ & 0.01 & (1.14) & 0.00 & $(1.21)$ \\
\hline Number of labs & 13.69 & $(5.64)$ & 14.25 & $(5.58)$ & 15.39 & $(5.52)$ & 15.35 & $(5.73)$ & 17.33 & $(6.20)$ \\
\hline Years AP teaching & 6.34 & $(5.56)$ & 6.33 & $(6.05)$ & 6.70 & $(6.23)$ & 6.58 & $(6.27)$ & 5.85 & (6.04) \\
\hline $\begin{array}{l}\text { Years AP redesign } \\
\text { experience }\end{array}$ & 1.90 & $(0.30)$ & 2.62 & $(0.72)$ & --- & --- & 1.87 & $(0.34)$ & --- & --- \\
\hline Self-efficacy & 0.03 & $(1.33)$ & 0.06 & $(1.30)$ & 0.03 & $(1.32)$ & 0.03 & $(1.32)$ & -0.05 & (1.27) \\
\hline $\begin{array}{l}\text { Importance of PD for } \\
\text { AP scores }\end{array}$ & 408 & & 4.04 & $(0) 78)$ & 3.93 & & & & & \\
\hline \multicolumn{11}{|c|}{ PD Characteristics } \\
\hline Number convent. PD & 1.80 & $(1.22)$ & 1.73 & $(1.24)$ & 1.85 & $(1.12)$ & 1.71 & $(1.19)$ & 1.57 & (1.12) \\
\hline Number unconvent. PD & 5.00 & $(1.37)$ & 6.70 & $(1.70)$ & 4.13 & $(1.41)$ & 5.83 & (1.69) & 6.22 & (2.24) \\
\hline $\begin{array}{l}\text { PD includes active } \\
\text { learning }\end{array}$ & 2.05 & $(1.29)$ & 1.89 & $(1.29)$ & 2.10 & $(1.16)$ & 1.81 & $(1.19)$ & 2.14 & (1.37) \\
\hline $\begin{array}{l}\text { PD has responsive } \\
\text { agenda }\end{array}$ & 2.90 & $(1.41)$ & 2.81 & $(1.48)$ & 2.83 & $(1.29)$ & 2.70 & $(1.44)$ & 2.66 & $(1.51)$ \\
\hline $\begin{array}{l}\text { PD focuses on student } \\
\text { work }\end{array}$ & 2.21 & $(1.26)$ & 2.25 & $(1.34)$ & 2.12 & $(1.15)$ & 2.17 & $(1.28)$ & 1.99 & (1.28) \\
\hline PD models teaching & 2.24 & $(1.30)$ & 2.31 & $(1.39)$ & 2.23 & $(1.20)$ & 2.20 & $(1.32)$ & 2.21 & $(1.40)$ \\
\hline $\begin{array}{l}\text { PD helps relationship } \\
\text { building }\end{array}$ & 3.03 & $(1.48)$ & 2.95 & $(1.56)$ & 2.92 & & 2.70 & $(1.47)$ & 2.81 & $(1.59)$ \\
\hline PD supports instruction & 3.06 & $(1.41)$ & 3.03 & $(1.52)$ & 3.10 & $(1.31)$ & 2.96 & $(1.45)$ & 2.74 & (1.51) \\
\hline Duration convent. PD & 36.0 & $(48.3)$ & 32.6 & (39.8) & 38.5 & $(38.0)$ & 27.7 & (31.3) & 34.5 & (33.2) \\
\hline
\end{tabular}


Table 4. Percent of level-2 variance accounted for by blocks of covariates

\begin{tabular}{lcccccc}
\hline \multicolumn{1}{c}{ Model } & $\begin{array}{c}\text { Block 1 } \\
{[\%]}\end{array}$ & $\begin{array}{c}\text { Block 2 } \\
{[\%]}\end{array}$ & Block 3 [\%] & $\begin{array}{c}\text { Block 4 } \\
{[\%]}\end{array}$ & $\begin{array}{c}\text { Remaining } \\
{[\%]}\end{array}$ & $\begin{array}{c}\text { Full } \\
\text { model } \\
\text { ICC }\end{array}$ \\
\hline Biology Year 3 & 44.42 & 2.29 & 11.09 & 1.95 & 40.26 & 0.19 \\
Biology Year 2 & 41.27 & 1.68 & 13.66 & 1.59 & 41.80 & 0.21 \\
Chemistry Year 2 & 31.86 & 1.33 & 22.68 & 1.20 & 42.93 & 0.27 \\
Chemistry Year 1 & 28.30 & $<1.00$ & 19.47 & 2.33 & 49.12 & 0.29 \\
Physics Year 1 & 36.73 & 1.09 & 15.30 & $<1.00$ & 46.23 & 0.23 \\
\hline
\end{tabular}

Note. Block 1 - students' PSAT scores, Block 2 - Mothers' educational attainment, Block 3 school, teacher, and teaching variables, Block 4 - teacher PD participation characteristics. 
Table 5. Meta-regression results predicting relationships on students' AP scores.

\begin{tabular}{|c|c|c|c|c|c|c|c|c|}
\hline Variable & $\widehat{\log (O R)}$ & $S E$ & $z$ & $p$ & $\begin{array}{c}\text { Lower } \\
95 \% \\
\text { CI }\end{array}$ & $\begin{array}{l}\text { Upper } \\
95 \% \text { CI }\end{array}$ & $\begin{array}{c}\text { Test for } \\
\text { Heterogeneit } \\
y(Q)\end{array}$ & $p$ \\
\hline \multicolumn{9}{|c|}{ Student Characteristics } \\
\hline PSAT scores & 1.795 & 0.104 & 17.181 & $<0.001$ & 1.590 & 2.000 & 488.294 & $<0.001$ \\
\hline \multicolumn{9}{|c|}{ Mother’s educational attainment (vs. no post-secondary) } \\
\hline Post-secondary & 0.012 & 0.021 & 0.579 & 0.563 & -0.029 & 0.054 & 4.137 & 0.388 \\
\hline Bachelor's degree & 0.134 & 0.026 & 5.204 & $<0.001$ & 0.083 & 0.184 & 6.987 & 0.137 \\
\hline Graduate degree & 0.175 & 0.038 & 4.580 & $<0.001$ & 0.100 & 0.250 & 13.716 & 0.008 \\
\hline \multicolumn{9}{|c|}{ School Characteristics } \\
\hline $\begin{array}{l}\text { Percentage free- or } \\
\text { reduced-lunch }\end{array}$ & -1.917 & 0.152 & -12.594 & $<0.001$ & -2.215 & -1.619 & 16.882 & 0.002 \\
\hline \multicolumn{9}{|c|}{ District-funding for materials (vs. $\$ 200-\$ 300$ ) } \\
\hline Funding $<\$ 200$ & 0.121 & 0.035 & 3.470 & $<0.001$ & 0.052 & 0.189 & 3.524 & 0.474 \\
\hline Funding $>\$ 300$ & -0.019 & 0.045 & -0.421 & 0.674 & -0.106 & 0.069 & 4.111 & 0.391 \\
\hline Administrative support & 0.032 & 0.016 & 2.046 & 0.041 & 0.001 & 0.063 & 2.318 & 0.678 \\
\hline \multicolumn{9}{|c|}{ Teacher and Teaching Characteristics } \\
\hline Self-efficacy & 0.076 & 0.019 & 4.041 & $<0.001$ & 0.039 & 0.113 & 5.638 & 0.228 \\
\hline $\begin{array}{l}\text { Importance of PD for } \\
\text { AP scores }\end{array}$ & -0.061 & 0.021 & -2.844 & 0.004 & -0.103 & -0.019 & 6.777 & 0.148 \\
\hline Years teaching AP & 0.021 & 0.005 & 4.657 & $<0.001$ & 0.012 & 0.030 & 10.638 & 0.031 \\
\hline $\begin{array}{l}\text { Years AP redesign } \\
\text { experience }\end{array}$ & 0.155 & 0.084 & 1.835 & 0.067 & -0.011 & 0.320 & 4.106 & 0.128 \\
\hline Number of labs & 0.029 & 0.009 & 3.340 & $<0.001$ & 0.012 & 0.045 & 32.698 & $<0.001$ \\
\hline $\begin{array}{l}\text { Hours of AP instruction } \\
\text { (in } 10 \mathrm{~h} \text { ) }\end{array}$ & 0.029 & 0.003 & 9.375 & $<0.001$ & 0.023 & 0.035 & 1.968 & 0.742 \\
\hline $\begin{array}{l}\text { Enactment of AP } \\
\text { curriculum elements }\end{array}$ & -0.145 & 0.017 & -8.465 & $<0.001$ & -0.178 & -0.111 & 3.168 & 0.530 \\
\hline $\begin{array}{l}\text { Enactment of AP } \\
\text { practice elements }\end{array}$ & 0.055 & 0.018 & 3.102 & 0.002 & 0.020 & 0.089 & 1.178 & 0.882 \\
\hline Curriculum X Practices & 0.020 & 0.015 & 1.343 & 0.179 & -0.009 & 0.048 & 2.794 & 0.593 \\
\hline \multicolumn{9}{|c|}{ PD Characteristics } \\
\hline Number convent. PD & 0.017 & 0.021 & 0.796 & 0.426 & -0.025 & 0.059 & 5.601 & 0.231 \\
\hline Number unconvent. PD & 0.011 & 0.011 & 1.007 & 0.314 & -0.011 & 0.033 & 1.125 & 0.890 \\
\hline $\begin{array}{l}\text { PD includes active } \\
\text { learning }\end{array}$ & -0.136 & 0.038 & -3.609 & $<0.001$ & -0.210 & -0.062 & 10.986 & 0.027 \\
\hline $\begin{array}{l}\text { PD focuses on student } \\
\text { work }\end{array}$ & -0.092 & 0.023 & -3.919 & $<0.001$ & -0.138 & -0.046 & 1.701 & 0.791 \\
\hline PD models teaching & -0.062 & 0.025 & -2.534 & 0.011 & -0.111 & -0.014 & 1.833 & 0.767 \\
\hline $\begin{array}{l}\text { PD helps relationship } \\
\text { building }\end{array}$ & 0.000 & 0.036 & 0.009 & 0.993 & -0.070 & 0.070 & 6.226 & 0.183 \\
\hline $\begin{array}{l}\text { PD has responsive } \\
\text { agenda }\end{array}$ & 0.071 & 0.028 & 2.520 & 0.012 & 0.016 & 0.126 & 1.158 & 0.885 \\
\hline PD supports instruction & 0.149 & 0.060 & 2.463 & 0.014 & 0.030 & 0.267 & 13.613 & 0.009 \\
\hline Duration convent. PD & 0.001 & 0.001 & 1.765 & 0.078 & 0.000 & 0.002 & 1.387 & 0.845 \\
\hline
\end{tabular}




\section{Supplemental Materials}

Supplemental Table S1. Biology 2015: Multi-level ordered logistic regression analysis, Biology Year 3.

\begin{tabular}{|c|c|c|c|c|c|c|c|c|c|c|c|c|}
\hline \multirow[b]{2}{*}{ Variable } & \multicolumn{3}{|c|}{ Model 1} & \multicolumn{3}{|c|}{ Model 2} & \multicolumn{3}{|c|}{ Model 3} & \multicolumn{3}{|c|}{ Model 4} \\
\hline & OR & SE & $\mathrm{z}$ & OR & $\mathrm{SE}$ & $\mathrm{z}$ & OR & $\mathrm{SE}$ & $\mathrm{z}$ & OR & SE & $\mathrm{z}$ \\
\hline \multicolumn{13}{|l|}{ Level 1} \\
\hline PSAT score & $8.316 * * *$ & 0.186 & 94.88 & $8.086 * * *$ & 0.182 & 92.77 & $7.845^{* * *}$ & 0.177 & 91.24 & $7.846 * * *$ & 0.177 & 91.29 \\
\hline Ed level: Some post-secondary & & & & $1.101 *$ & 0.050 & 2.14 & 1.065 & 0.048 & 1.40 & 1.066 & 0.048 & 1.42 \\
\hline Ed level: Bachelor's & & & & $1.291 * * *$ & 0.057 & 5.82 & $1.217 * * *$ & 0.053 & 4.46 & $1.218 * * *$ & 0.053 & 4.48 \\
\hline Ed level: Graduate degree & & & & $1.430 * * *$ & 0.068 & 7.57 & $1.341 * * *$ & 0.064 & 6.19 & $1.344 * * *$ & 0.064 & 6.24 \\
\hline \multicolumn{13}{|l|}{ Level 2} \\
\hline Funding: $<\$ 200$ & & & & & & & 1.135 & 0.079 & 1.81 & $1.156^{*}$ & 0.080 & 2.10 \\
\hline Funding: $>\$ 300$ & & & & & & & 0.905 & 0.084 & -1.07 & 0.894 & 0.082 & -1.22 \\
\hline$\%$ FRLP & & & & & & & $0.200 * * *$ & 0.029 & -11.05 & $0.232 * * *$ & 0.034 & -10.04 \\
\hline Administrative support & & & & & & & 1.050 & 0.034 & 1.51 & 1.040 & 0.033 & 1.25 \\
\hline Hours of AP instruction (in $10 \mathrm{~h}$ ) & & & & & & & $1.028 * * *$ & 0.006 & 4.69 & $1.026 * * *$ & 0.006 & 4.41 \\
\hline Enactment: Practice elements & & & & & & & 1.056 & 0.038 & 1.51 & $1.078 *$ & 0.039 & 2.09 \\
\hline Enactment: Curriculum elements & & & & & & & $0.901 * *$ & 0.031 & -3.05 & $0.903 * *$ & 0.031 & -2.97 \\
\hline Int: Practice $*$ Curriculum elements & & & & & & & 1.055 & 0.030 & 1.89 & 1.054 & 0.030 & 1.87 \\
\hline Number of labs & & & & & & & 1.009 & 0.006 & 1.37 & 1.006 & 0.006 & 0.91 \\
\hline Years AP teaching experience & & & & & & & $1.017 * *$ & 0.006 & 2.74 & $1.017 * *$ & 0.006 & 2.76 \\
\hline Years AP redesign experience & & & & & & & 1.049 & 0.056 & 0.89 & 1.015 & 0.055 & 0.28 \\
\hline Self-efficacy & & & & & & & 1.024 & 0.032 & 0.74 & 1.033 & 0.032 & 1.04 \\
\hline Importance of PD for AP scores & & & & & & & 1.005 & 0.034 & 0.15 & 0.998 & 0.034 & -0.07 \\
\hline Number of above-the-line PD & & & & & & & & & & 0.978 & 0.034 & -0.63 \\
\hline Number of below-the-line PD & & & & & & & & & & 1.023 & 0.020 & 1.16 \\
\hline PD includes active learning & & & & & & & & & & $0.816 * * *$ & 0.036 & -4.54 \\
\hline PD has responsive agenda & & & & & & & & & & $1.133 *$ & 0.067 & 2.10 \\
\hline PD focuses on student work & & & & & & & & & & $0.880 *$ & 0.045 & -2.52 \\
\hline PD models teaching & & & & & & & & & & 0.960 & 0.050 & -0.80 \\
\hline PD helps relationship building & & & & & & & & & & 1.018 & 0.068 & 0.27 \\
\hline PD effectively supports instruction & & & & & & & & & & 1.159 & 0.092 & 1.87 \\
\hline Above-the-line PD duration in hours & & & & & & & & & & 1.001 & 0.001 & 1.11 \\
\hline Cut point 1 & $-5.011 * * *$ & 0.057 & -87.63 & $-4.825 * * *$ & 0.064 & -75.30 & $-4.759 * * *$ & 0.164 & -29.03 & $-4.839 * * *$ & 0.165 & -29.25 \\
\hline Cut point 2 & $-1.495 * * *$ & 0.039 & -38.66 & $-1.312 * * *$ & 0.049 & -26.81 & $-1.232 * * *$ & 0.159 & -7.75 & $-1.310 * * *$ & 0.160 & -8.18 \\
\hline Cut point 3 & $1.560 * * *$ & 0.039 & 39.97 & $1.750 * * *$ & 0.050 & 35.21 & $1.830 * * *$ & 0.159 & 11.49 & $1.752 * * *$ & 0.160 & 10.92 \\
\hline Cut point 4 & $4.565 * * *$ & 0.053 & 86.77 & $4.758 * * *$ & 0.061 & 78.12 & $4.828 * * *$ & 0.163 & 29.59 & $4.750 * * *$ & 0.164 & 28.90 \\
\hline \multicolumn{13}{|c|}{ Random Effects } \\
\hline Level 2 variance & 1.078 & & & 1.034 & & & 0.819 & & & 0.781 & & \\
\hline \multicolumn{13}{|c|}{ Deviance Statistics } \\
\hline
\end{tabular}




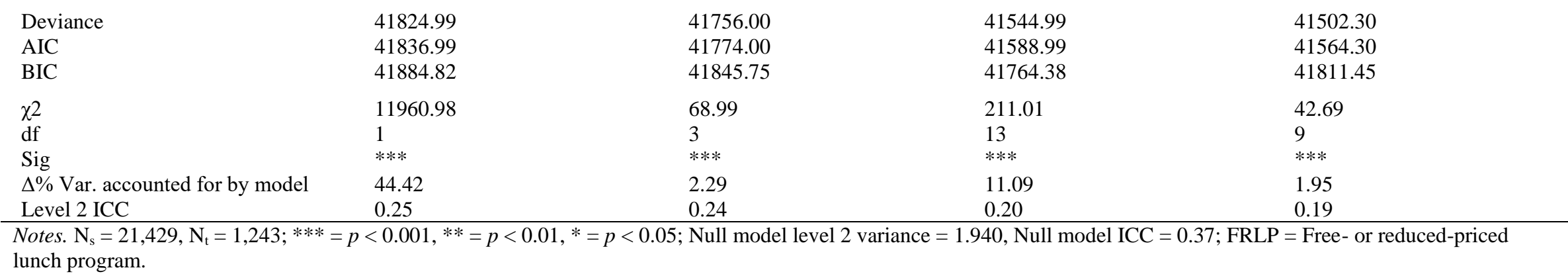


Supplemental Table S2. Biology 2014: Multi-level ordered logistic regression analysis, Biology Year 2.

\begin{tabular}{|c|c|c|c|c|c|c|c|c|c|c|c|c|}
\hline \multirow[b]{2}{*}{ Variable } & \multicolumn{3}{|c|}{ Model 1} & \multicolumn{3}{|c|}{ Model 2} & \multicolumn{3}{|c|}{ Model 3} & \multicolumn{3}{|c|}{ Model 4} \\
\hline & OR & SE & $\mathrm{z}$ & OR & SE & $\mathrm{z}$ & OR & SE & $\mathrm{z}$ & OR & SE & $\mathrm{z}$ \\
\hline \multicolumn{13}{|l|}{ Level 1} \\
\hline PSAT score & $7.953 * * *$ & 0.163 & 101.42 & $7.770 * * *$ & 0.160 & 99.28 & $7.573 * * *$ & 0.157 & 97.95 & $7.572 * * *$ & 0.156 & 97.97 \\
\hline Ed level: Some post-secondary & & & & 1.056 & 0.044 & 1.32 & 1.027 & 0.043 & 0.64 & 1.027 & 0.043 & 0.65 \\
\hline Ed level: Bachelor's & & & & $1.257 * * *$ & 0.051 & 5.63 & $1.200 * * *$ & 0.049 & 4.49 & $1.200 * * *$ & 0.049 & 4.49 \\
\hline Ed level: Graduate degree & & & & $1.310 * * *$ & 0.057 & 6.19 & $1.247 * * *$ & 0.054 & 5.07 & $1.247 * * *$ & 0.054 & 5.07 \\
\hline \multicolumn{13}{|l|}{ Level 2} \\
\hline Funding: $<\$ 200$ & & & & & & & $1.240 * *$ & 0.089 & 2.99 & $1.237 * *$ & 0.088 & 2.99 \\
\hline Funding: $>\$ 300$ & & & & & & & 0.994 & 0.093 & -0.07 & 0.971 & 0.090 & -0.32 \\
\hline$\%$ FRLP & & & & & & & $0.148 * * *$ & 0.022 & -12.77 & $0.164 * * *$ & 0.024 & -12.11 \\
\hline Administrative support & & & & & & & 1.061 & 0.034 & 1.83 & $1.073 *$ & 0.035 & 2.18 \\
\hline Hours of AP instruction (in $10 \mathrm{~h}$ ) & & & & & & & $1.027 * * *$ & 0.006 & 4.45 & $1.026 * * *$ & 0.006 & 4.24 \\
\hline Enactment: Practice elements & & & & & & & 1.061 & 0.038 & 1.68 & 1.062 & 0.037 & 1.70 \\
\hline Enactment: Curriculum elements & & & & & & & $0.874 * * *$ & 0.031 & -3.80 & $0.873 * * *$ & 0.031 & -3.80 \\
\hline Int: Practice $*$ Curriculum elements & & & & & & & 1.009 & 0.032 & 0.29 & 1.007 & 0.031 & 0.22 \\
\hline Number of labs & & & & & & & $1.022 * * *$ & 0.006 & 3.68 & $1.023 * * *$ & 0.006 & 3.74 \\
\hline Years AP teaching experience & & & & & & & 1.008 & 0.006 & 1.19 & 1.006 & 0.006 & 0.96 \\
\hline Years AP redesign experience & & & & & & & $1.314^{*}$ & 0.154 & 2.34 & 1.224 & 0.143 & 1.73 \\
\hline Self-efficacy & & & & & & & 1.030 & 0.033 & 0.91 & 1.035 & 0.033 & 1.09 \\
\hline Importance of PD for AP scores & & & & & & & 0.980 & 0.033 & -0.61 & 0.971 & 0.033 & -0.87 \\
\hline Number of above-the-line PD & & & & & & & & & & 1.057 & 0.036 & 1.60 \\
\hline Number of below-the-line PD & & & & & & & & & & 1.025 & 0.025 & 1.04 \\
\hline PD includes active learning & & & & & & & & & & $0.839 * * *$ & 0.035 & -4.21 \\
\hline PD has responsive agenda & & & & & & & & & & 1.072 & 0.062 & 1.20 \\
\hline PD focuses on student work & & & & & & & & & & 0.912 & 0.044 & -1.90 \\
\hline PD models teaching & & & & & & & & & & 0.948 & 0.046 & -1.10 \\
\hline PD helps relationship building & & & & & & & & & & 1.018 & 0.060 & 0.31 \\
\hline PD effectively supports instruction & & & & & & & & & & 1.093 & 0.076 & 1.29 \\
\hline Above-the-line PD duration in hours & & & & & & & & & & 1.001 & 0.001 & 0.98 \\
\hline Cut point 1 & $-4.832 * * *$ & 0.054 & -89.54 & $-4.687 * * *$ & 0.060 & -77.56 & $-4.191 * * *$ & 0.235 & -17.82 & $-4.334 * * *$ & 0.235 & -18.42 \\
\hline Cut point 2 & $-1.494 * * *$ & 0.039 & -38.08 & $-1.346 * * *$ & 0.048 & -27.81 & $-0.831 * * *$ & 0.233 & -3.57 & $-0.974 * * *$ & 0.233 & -4.18 \\
\hline Cut point 3 & $1.444 * * *$ & 0.039 & 36.88 & $1.596 * * *$ & 0.049 & 32.83 & $2.110 * * *$ & 0.233 & 9.05 & $1.967 * * *$ & 0.233 & 8.43 \\
\hline Cut point 4 & $4.382 * * *$ & 0.049 & 88.60 & $4.534 * * *$ & 0.057 & 79.41 & $5.037 * * *$ & 0.235 & 21.41 & $4.894 * * *$ & 0.235 & 20.81 \\
\hline \multicolumn{13}{|c|}{ Random Effects } \\
\hline Level 2 variance & 1.252 & & & 1.216 & & & 0.925 & & & 0.891 & & \\
\hline \multicolumn{13}{|c|}{ Deviance Statistics } \\
\hline Deviance & 50051.24 & & & 49994.14 & & & 49727.51 & & & 49693.70 & & \\
\hline AIC & 50063.24 & & & 50012.14 & & & 49771.51 & & & 49755.69 & & \\
\hline
\end{tabular}




\begin{tabular}{lllll} 
BIC & 50112.02 & 50085.32 & 49950.39 & 50007.75 \\
$\chi 2$ & 13449.05 & 57.10 & 266.63 & 33.82 \\
df & 1 & 3 & 13 & 9 \\
Sig & $* * *$ & $* * *$ & $* * *$ & $* * *$ \\
$\Delta \%$ Var. accounted for by model & 41.27 & 1.68 & 13.66 & 1.59 \\
Level 2 ICC & 0.28 & 0.27 & 0.22 & 0.21 \\
\hline
\end{tabular}

Notes. $\mathrm{N}_{\mathrm{s}}=25,108, \mathrm{~N}_{\mathrm{t}}=1,265 ; * * *=p<0.001, * *=p<0.01, *=p<0.05 ;$ Null model level 2 variance $=2.132$, Null model ICC $=0.39 ;$ FRLP $=$ Free- or reduced-priced lunch program. 
Supplemental Table S3. Chemistry 2015: Multi-level ordered logistic regression analysis, Chemistry Year 2.

\begin{tabular}{|c|c|c|c|c|c|c|c|c|c|c|c|c|}
\hline \multirow[b]{2}{*}{ Variable } & \multicolumn{3}{|c|}{ Model 1} & \multicolumn{3}{|c|}{ Model 2} & \multicolumn{3}{|c|}{ Model 3} & \multicolumn{3}{|c|}{ Model 4} \\
\hline & OR & SE & $\mathrm{z}$ & OR & SE & $\mathrm{z}$ & OR & SE & $\mathrm{z}$ & OR & SE & $\mathrm{z}$ \\
\hline \multicolumn{13}{|l|}{ Level 1} \\
\hline PSAT score & $5.565 * * *$ & 0.113 & 84.18 & $5.452 * * *$ & 0.113 & 81.89 & $5.320 * * *$ & 0.110 & 80.81 & $5.323 * * *$ & 0.110 & 80.85 \\
\hline Ed level: Some post-secondary & & & & 1.056 & 0.050 & 1.13 & 1.026 & 0.049 & 0.54 & 1.026 & 0.049 & 0.53 \\
\hline Ed level: Bachelor's & & & & $1.169 * *$ & 0.053 & 3.45 & $1.109^{*}$ & 0.050 & 2.29 & $1.109 *$ & 0.050 & 2.29 \\
\hline Ed level: Graduate degree & & & & $1.259 * * *$ & 0.060 & 4.81 & $1.186 * * *$ & 0.057 & 3.57 & $1.185 * * *$ & 0.057 & 3.55 \\
\hline \multicolumn{13}{|l|}{ Level 2} \\
\hline Funding: $<\$ 200$ & & & & & & & 1.108 & 0.091 & 1.24 & 1.124 & 0.092 & 1.43 \\
\hline Funding: $>\$ 300$ & & & & & & & 1.127 & 0.116 & 1.16 & 1.145 & 0.118 & 1.32 \\
\hline$\%$ FRLP & & & & & & & $0.085 * * *$ & 0.015 & -13.55 & $0.095 * * *$ & 0.017 & -12.84 \\
\hline Administrative support & & & & & & & 0.999 & 0.036 & -0.02 & 0.999 & 0.036 & -0.03 \\
\hline Hours of AP instruction (in $10 \mathrm{~h}$ ) & & & & & & & $1.030 * * *$ & 0.007 & 4.13 & $1.030 * * *$ & 0.007 & 4.14 \\
\hline Enactment: Practice elements & & & & & & & 1.080 & 0.044 & 1.91 & 1.072 & 0.044 & 1.71 \\
\hline Enactment: Curriculum elements & & & & & & & $0.821 * * *$ & 0.033 & -4.85 & $0.823 * * *$ & 0.034 & -4.75 \\
\hline Int: Practice $*$ Curriculum elements & & & & & & & 1.036 & 0.035 & 1.07 & 1.042 & 0.035 & 1.24 \\
\hline Number of labs & & & & & & & $1.053 * * *$ & 0.007 & 7.36 & $1.053 * * *$ & 0.007 & 7.33 \\
\hline Years AP teaching experience & & & & & & & $1.027 * * *$ & 0.007 & 4.03 & $1.026 * * *$ & 0.007 & 3.87 \\
\hline Years AP redesign experience & & & & & & & $1.345^{*}$ & 0.171 & 2.33 & 1.271 & 0.163 & 1.87 \\
\hline Self-efficacy & & & & & & & $1.120 * *$ & 0.042 & 3.00 & $1.109 * *$ & 0.042 & 2.76 \\
\hline Importance of PD for AP scores & & & & & & & $0.890 * *$ & 0.035 & -2.95 & $0.884 * *$ & 0.035 & -3.10 \\
\hline Number of above-the-line PD & & & & & & & & & & 1.014 & 0.043 & 0.33 \\
\hline Number of below-the-line PD & & & & & & & & & & 1.006 & 0.024 & 0.26 \\
\hline PD includes active learning & & & & & & & & & & $0.824 * * *$ & 0.044 & -3.65 \\
\hline PD has responsive agenda & & & & & & & & & & 1.077 & 0.073 & 1.10 \\
\hline PD focuses on student work & & & & & & & & & & 0.962 & 0.056 & -0.67 \\
\hline PD models teaching & & & & & & & & & & 0.965 & 0.057 & -0.59 \\
\hline PD helps relationship building & & & & & & & & & & 0.947 & 0.066 & -0.78 \\
\hline PD effectively supports instruction & & & & & & & & & & $1.253 * *$ & 0.092 & 3.07 \\
\hline Above-the-line PD duration in hours & & & & & & & & & & 1.002 & 0.002 & 1.19 \\
\hline Cut point 1 & $-2.594 * * *$ & 0.050 & -52.38 & $-2.471 * * *$ & 0.059 & -41.56 & $-2.017 * * *$ & 0.252 & -8.02 & $-2.116^{* * *}$ & 0.253 & -8.36 \\
\hline Cut point 2 & $-0.267 * * *$ & 0.046 & -5.84 & $-0.143 * * *$ & 0.057 & -2.52 & $0.319 * * *$ & 0.251 & 1.27 & $0.221 * * *$ & 0.253 & 0.87 \\
\hline Cut point 3 & $2.086 * * *$ & 0.048 & 43.21 & $2.212 * * *$ & 0.059 & 37.54 & $2.672 * * *$ & 0.252 & 10.61 & $2.575 * * *$ & 0.253 & 10.17 \\
\hline Cut point 4 & $4.112 * * *$ & 0.055 & 74.43 & $4.237 * * *$ & 0.065 & 65.55 & $4.694 * * *$ & 0.253 & 18.53 & $4.597 * * *$ & 0.255 & 18.05 \\
\hline \multicolumn{13}{|c|}{ Random Effects } \\
\hline Level 2 variance & 1.900 & & & 1.860 & & & 1.229 & & & 1.200 & & \\
\hline \multicolumn{13}{|c|}{ Deviance Statistics } \\
\hline Deviance & 48133.58 & & & 48104.57 & & & 47672.81 & & & 47645.20 & & \\
\hline $\mathrm{AIC}$ & 48145.58 & & & 48122.57 & & & 47716.81 & & & 47707.21 & & \\
\hline $\mathrm{BIC}$ & 48193.35 & & & 48194.22 & & & 47891.97 & & & 47954.03 & & \\
\hline
\end{tabular}




\begin{tabular}{lllll}
$\chi 2$ & 8532.51 & 29.01 & 431.76 & 27.60 \\
$\mathrm{df}$ & 1 & 3 & 13 & 9 \\
$\mathrm{Sig}$ & $* * *$ & $* * *$ & $* * *$ & $* *$ \\
$\Delta \%$ Var. accounted for by model & 31.86 & 1.33 & 22.68 & 1.20 \\
Level 2 ICC & 0.37 & 0.36 & 0.27 & 0.27 \\
\hline
\end{tabular}

Notes. $\mathrm{N}_{\mathrm{s}}=21,204, \mathrm{~N}_{\mathrm{t}}=1,219 ; * * *=p<0.001, * *=p<0.01, *=p<0.05 ;$ Null model level 2 variance $=2.784$, Null model ICC $=0.46 ;$ FRLP $=$ Free- or reduced-priced lunch program. 
Supplemental Table S4. Chemistry 2014: Multi-level ordered logistic regression analysis, Chemistry Year 1.

\begin{tabular}{|c|c|c|c|c|c|c|c|c|c|c|c|c|}
\hline \multirow[b]{2}{*}{ Variable } & \multicolumn{3}{|c|}{ Model 1} & \multicolumn{3}{|c|}{ Model 2} & \multicolumn{3}{|c|}{ Model 3} & \multicolumn{3}{|c|}{ Model 4} \\
\hline & OR & SE & $\mathrm{z}$ & OR & SE & $\mathrm{z}$ & OR & SE & $\mathrm{z}$ & OR & SE & $\mathrm{z}$ \\
\hline \multicolumn{13}{|l|}{ Level 1} \\
\hline PSAT score & $5.230 * * *$ & 0.094 & 92.24 & $5.159 * * *$ & 0.094 & 90.17 & $5.046 * * *$ & 0.092 & 88.98 & $5.048 * * *$ & 0.092 & 89.03 \\
\hline Ed level: Some post-secondary & & & & 0.977 & 0.041 & -0.55 & 0.946 & 0.040 & -1.30 & 0.945 & 0.040 & -1.33 \\
\hline Ed level: Bachelor's & & & & $1.122 * *$ & 0.045 & 2.86 & 1.067 & 0.043 & 1.62 & 1.066 & 0.043 & 1.59 \\
\hline Ed level: Graduate degree & & & & $1.143 * *$ & 0.049 & 3.13 & 1.087 & 0.046 & 1.95 & 1.086 & 0.046 & 1.93 \\
\hline \multicolumn{13}{|l|}{ Level 2} \\
\hline Funding: $<\$ 200$ & & & & & & & 0.983 & 0.078 & -0.21 & 1.018 & 0.080 & 0.23 \\
\hline Funding: $>\$ 300$ & & & & & & & 0.880 & 0.087 & -1.30 & 0.910 & 0.089 & -0.97 \\
\hline$\%$ FRLP & & & & & & & $0.108 * * *$ & 0.019 & -12.95 & $0.122 * * *$ & 0.021 & -12.35 \\
\hline Administrative support & & & & & & & 1.034 & 0.037 & 0.93 & 1.025 & 0.036 & 0.70 \\
\hline Hours of AP instruction (in 10h) & & & & & & & $1.039 * * *$ & 0.007 & 5.72 & $1.037 * * *$ & 0.007 & 5.46 \\
\hline Enactment: Practice elements & & & & & & & 1.011 & 0.039 & 0.28 & 1.023 & 0.039 & 0.60 \\
\hline Enactment: Curriculum elements & & & & & & & $0.847 * * *$ & 0.032 & -4.38 & $0.859 * * *$ & 0.033 & -4.03 \\
\hline Int: Practice $*$ Curriculum elements & & & & & & & 0.990 & 0.032 & -0.32 & 0.989 & 0.032 & -0.33 \\
\hline Number of labs & & & & & & & $1.047 * * *$ & 0.007 & 6.67 & $1.045 * * *$ & 0.007 & 6.43 \\
\hline Years AP teaching experience & & & & & & & $1.033 * * *$ & 0.006 & 5.55 & $1.032 * * *$ & 0.006 & 5.50 \\
\hline Years AP redesign experience & & & & & & & --- & --- & --- & --- & --- & --- \\
\hline Self-efficacy & & & & & & & $1.106^{* *}$ & 0.040 & 2.77 & $1.102 * *$ & 0.039 & 2.71 \\
\hline Importance of PD for AP scores & & & & & & & 0.953 & 0.034 & -1.33 & 0.935 & 0.034 & -1.86 \\
\hline Number of above-the-line PD & & & & & & & & & & 1.068 & 0.041 & 1.70 \\
\hline Number of below-the-line PD & & & & & & & & & & 1.000 & 0.026 & -0.01 \\
\hline PD includes active learning & & & & & & & & & & $0.893 *$ & 0.042 & -2.41 \\
\hline PD has responsive agenda & & & & & & & & & & 1.050 & 0.060 & 0.85 \\
\hline PD focuses on student work & & & & & & & & & & $0.889^{*}$ & 0.042 & -2.50 \\
\hline PD models teaching & & & & & & & & & & $0.886^{*}$ & 0.045 & -2.41 \\
\hline PD helps relationship building & & & & & & & & & & 0.918 & 0.053 & -1.49 \\
\hline PD effectively supports instruction & & & & & & & & & & $1.348 * * *$ & 0.080 & 5.04 \\
\hline Above-the-line PD duration in hours & & & & & & & & & & 1.001 & 0.001 & 1.40 \\
\hline Cut point 1 & $-2.696 * * *$ & 0.045 & -59.31 & $-2.628 * * *$ & 0.054 & -48.34 & $-2.842 * * *$ & 0.073 & -38.94 & $-2.833 * * *$ & 0.072 & -39.23 \\
\hline Cut point 2 & $-0.286 * * *$ & 0.042 & -6.83 & $-0.217 * * *$ & 0.052 & -4.22 & $-0.427 * * *$ & 0.071 & -6.06 & $-0.418 * * *$ & 0.070 & -5.99 \\
\hline Cut point 3 & $1.826 * * *$ & 0.043 & 41.99 & $1.896^{* * *}$ & 0.053 & 35.85 & $1.685^{* * *}$ & 0.071 & 23.62 & $1.694 * * *$ & 0.071 & 24.00 \\
\hline Cut point 4 & $3.751 * * *$ & 0.049 & 77.33 & $3.821 * * *$ & 0.057 & 67.03 & $3.606 * * *$ & 0.074 & 48.52 & $3.616 * * *$ & 0.074 & 49.13 \\
\hline \multicolumn{13}{|c|}{ Random Effects } \\
\hline Level 2 variance & 1.915 & & & 1.894 & & & 1.374 & & & 1.312 & & \\
\hline \multicolumn{13}{|c|}{ Deviance Statistics } \\
\hline Deviance & 61774.89 & & & 61750.32 & & & 61365.07 & & & 61312.53 & & \\
\hline AIC & 61786.99 & & & 61768.32 & & & 61407.07 & & & 61372.53 & & \\
\hline $\mathrm{BIC}$ & 61835.99 & & & 61841.96 & & & 61578.91 & & & 61618.02 & & \\
\hline
\end{tabular}




\begin{tabular}{lllll}
$\chi 2$ & 10115.90 & 24.57 & 385.25 & 52.53 \\
$\mathrm{df}$ & 1 & $3 * * *$ & 12 & 9 \\
$\mathrm{Sig}$ & $* * * * *$ & $* *$ & $* 4$ \\
$\Delta \%$ Var. accounted for by model & 28.30 & 0.79 & 19.47 & 2.33 \\
Level 2 ICC & 0.37 & 0.37 & 0.29 & 0.29 \\
\hline
\end{tabular}

Notes. $\mathrm{N}_{\mathrm{s}}=26,449, \mathrm{~N}_{\mathrm{t}}=1,443 ; * * *=p<0.001, * *=p<0.01, *=p<0.05$; Null model level 2 variance $=2.671$, Null model ICC $=0.45 ;$ FRLP $=$ Free- or reduced-priced lunch program. 
Supplemental Table S5. Physics 2015: Multi-level ordered logistic regression analysis, Physics Year 1.

\begin{tabular}{|c|c|c|c|c|c|c|c|c|c|c|c|c|}
\hline \multirow[b]{2}{*}{ Variable } & \multicolumn{3}{|c|}{ Model 1} & \multicolumn{3}{|c|}{ Model 2} & \multicolumn{3}{|c|}{ Model 3} & \multicolumn{3}{|c|}{ Model 4} \\
\hline & OR & SE & $\mathrm{z}$ & OR & SE & $\mathrm{z}$ & OR & SE & $\mathrm{z}$ & OR & SE & $\mathrm{z}$ \\
\hline \multicolumn{13}{|l|}{ Level 1} \\
\hline PSAT score & $1.612 * * *$ & 0.021 & 76.75 & $4.942 * * *$ & 0.105 & 74.95 & $4.853 * * *$ & 0.103 & 74.13 & $4.849 * * *$ & 0.103 & 74.10 \\
\hline Ed level: Some post-secondary & & & & 1.048 & 0.052 & 0.96 & 1.017 & 0.050 & 0.34 & 1.016 & 0.050 & 0.32 \\
\hline Ed level: Bachelor's & & & & $1.194 * * *$ & 0.056 & 3.80 & $1.139 * *$ & 0.053 & 2.77 & $1.138 * *$ & 0.053 & 2.76 \\
\hline Ed level: Graduate degree & & & & $1.176^{* *}$ & 0.059 & 3.24 & $1.121 *$ & 0.056 & 2.28 & $1.122 *$ & 0.056 & 2.29 \\
\hline \multicolumn{13}{|l|}{ Level 2} \\
\hline Funding: $<\$ 200$ & & & & & & & 1.136 & 0.101 & 1.44 & 1.125 & 0.100 & 1.33 \\
\hline Funding: $>\$ 300$ & & & & & & & 1.038 & 0.118 & 0.33 & 1.033 & 0.117 & 0.29 \\
\hline$\%$ FRLP & & & & & & & $0.155^{* * *} *$ & 0.030 & -9.75 & $0.160 * * *$ & 0.031 & -9.60 \\
\hline Administrative support & & & & & & & 1.020 & 0.041 & 0.50 & 1.022 & 0.041 & 0.56 \\
\hline Hours of AP instruction (in $10 \mathrm{~h}$ ) & & & & & & & $1.027 * *$ & 0.009 & 2.91 & $1.028 * *$ & 0.009 & 2.95 \\
\hline Enactment: Practice elements & & & & & & & 1.035 & 0.048 & 0.75 & 1.052 & 0.050 & 1.08 \\
\hline Enactment: Curriculum elements & & & & & & & $0.860 * * *$ & 0.035 & -3.68 & $0.871 * *$ & 0.037 & -3.28 \\
\hline Int: Practice $*$ Curriculum elements & & & & & & & 1.019 & 0.038 & 0.51 & 1.017 & 0.038 & 0.45 \\
\hline Number of labs & & & & & & & $1.018^{*}$ & 0.007 & 2.43 & $1.017 *$ & 0.007 & 2.28 \\
\hline Years AP teaching experience & & & & & & & $1.027 * * *$ & 0.007 & 4.16 & $1.027 * * *$ & 0.007 & 4.14 \\
\hline Years AP redesign experience & & & & & & & --- & --- & --- & --- & --- & --- \\
\hline Self-efficacy & & & & & & & $1.121 * *$ & 0.045 & 2.84 & $1.128 * *$ & 0.046 & 2.98 \\
\hline Importance of PD for AP scores & & & & & & & $0.910^{*}$ & 0.037 & -2.35 & $0.913 *$ & 0.037 & -2.22 \\
\hline Number of above-the-line PD & & & & & & & & & & 0.949 & 0.053 & -0.94 \\
\hline Number of below-the-line PD & & & & & & & & & & 1.002 & 0.019 & 0.10 \\
\hline PD includes active learning & & & & & & & & & & 1.022 & 0.063 & 0.35 \\
\hline PD has responsive agenda & & & & & & & & & & 1.039 & 0.077 & 0.52 \\
\hline PD focuses on student work & & & & & & & & & & 0.927 & 0.056 & -1.24 \\
\hline PD models teaching & & & & & & & & & & 0.954 & 0.065 & -0.69 \\
\hline PD helps relationship building & & & & & & & & & & 1.144 & 0.085 & 1.80 \\
\hline PD effectively supports instruction & & & & & & & & & & 0.940 & 0.083 & -0.70 \\
\hline Above-the-line PD duration in hours & & & & & & & & & & 0.999 & 0.002 & -0.33 \\
\hline Cut point 1 & $-1.549 * * *$ & 0.047 & -32.96 & $-1.441 * * *$ & 0.058 & -24.91 & $-1.466 * * *$ & 0.079 & -18.46 & $-1.470 * * *$ & 0.080 & -18.44 \\
\hline Cut point 2 & $0.745 * * *$ & 0.046 & 16.23 & $0.855^{* * *}$ & 0.057 & 14.95 & $0.833 * * *$ & 0.079 & 10.54 & $0.829 * * *$ & 0.079 & 10.45 \\
\hline Cut point 3 & $2.498 * * *$ & 0.049 & 50.66 & $2.609 * * *$ & 0.060 & 43.50 & $2.583 * * *$ & 0.081 & 31.89 & $2.579 * * *$ & 0.081 & 31.73 \\
\hline Cut point 4 & $4.677 * * *$ & 0.061 & 76.12 & $4.786 * * *$ & 0.070 & 68.23 & $4.755 * * *$ & 0.089 & 53.60 & $4.750 * * *$ & 0.089 & 53.39 \\
\hline \multicolumn{13}{|c|}{ Random Effects } \\
\hline Level 2 variance & 1.325 & & & 1.302 & & & 0.982 & & & 0.968 & & \\
\hline \multicolumn{13}{|c|}{ Deviance Statistics } \\
\hline Deviance & 42981.52 & & & 42961.44 & & & 42764.12 & & & 42753.58 & & \\
\hline $\mathrm{AIC}$ & 42993.52 & & & 42979.44 & & & 42806.12 & & & 42813.58 & & \\
\hline $\mathrm{BIC}$ & 43050.76 & & & 43050.30 & & & 42971.46 & & & 43049.79 & & \\
\hline
\end{tabular}




\begin{tabular}{|c|c|c|c|c|}
\hline$\chi^{2}$ & 7013.52 & 20.08 & 197.32 & 10.54 \\
\hline df & 1 & 3 & 12 & 9 \\
\hline Sig & $* * *$ & $* * *$ & $* * *$ & n.s. \\
\hline$\Delta \%$ Var. accounted for by model & 36.73 & 1.09 & 15.30 & 0.64 \\
\hline Level 2 ICC & 0.29 & 0.28 & 0.23 & 0.23 \\
\hline
\end{tabular}

